\title{
On several new or poorly-known Oriental Paradoxosomatidae (Diplopoda: Polydesmida), XIII
}

\section{О несколыких новых или плохоизученных ориенталыных Paradoxosomatidae (Diplopoda: Polydesmida), XIII}

\author{
S.I. Golovatch \\ С.И. Головач
}

Institute for Problems of Ecology and Evolution, Russian Academy of Sciences, Leninsky prospekt 33, Moscow 119071 Russia. E-mail: sgolovatch@yandex.ru

Институт проблем экологии и эволюции РАН, Ленинский проспект, 33, Москва 119071 Россия.

KEY WORDS: Diplopoda, Polydesmida, Paradoxosomatidae, taxonomy, new records, new genus, new species, China.

КЛЮЧЕВЫЕ СЛОВА: Diplopoda, Polydesmida, Paradoxosomatidae, таксономия, новые находки, новый род, новые виды, Китай.

ABSTRACT. This contribution is devoted to new records of several known, and to descriptions of the following 11 new, species from China: Tetracentrosternus hoffmani sp.n., Tylopus schawalleri sp.n., T. reductus sp.n., Kronopolites rugosus sp.n. and Antheromorpha rosea sp.n., all five from Yunnan, Inversispina trispina sp.n., from Sichuan, Hedinomorpha circofera sp.n., from Qinghai, as well as Anoplodesmus chinenis sp.n., Gonobelus martensi sp.n. and Sellanucheza jaegeri sp.n., all three from Shaanxi Province. In addition, a new genus, Sinomorpha gen.n. (Orthomorphini), is established for S. setosa sp.n., from Sichuan. Keys to all four Tylopus species reported from China, as well as to all four currently known species of Sellanucheza are given, the latter genus being relocated to the tribe Sulciferini, comb.n. The species Hedinomorpha jeekeli (Golovatch, 2009), from Shaanxi, is also relocated as a comb.n. ex Streptogonopus.

РЕЗЮМЕ. Данное сообщение посвящено находкам ряда известных, а также описаниям следующих 11 новых видов из Китая: Tetracentrosternus hoffmani sp.n., Tylopus schawalleri sp.n., T. reductus sp.n., Kronopolites rugosus sp.n. и Antheromorpha rosea sp.n., все пять из провинции Юннань, Inversispina trispina sp.n. из провинции Сычуань, Hedinomorpha circofera sp.n. из провинции Цинхай, а также Anoplodesmus chinenis sp.n., Gonobelus martensi sp.n. и Sellanucheza jaegeri sp.n., все три из провинции Шаанси. Кроме того, установлен новый род, Sinomorpha gen.n. (Orthomorphini), для S. setosa sp.n. из Сычуани. Даны ключи для определения всех четырех видов рода Tylopus, указанных для Китая, а также всех четырех пока известных видов рода Sellanucheza, притом этот последний род пе- ренесен в состав трибы Sulciferini, comb.n. Вид Hedinomorpha jeekeli (Golovatch, 2009) из Шаанси тоже перемещен в качестве comb.n. ex Streptogonopus.

\section{Introduction}

This paper is devoted to new records of several known, as well as to descriptions of one new genus and 12 new species of paradoxosomatid millipedes from China, mostly from Yunnan, Sichuan, Qinghai and Shaanxi provinces. The material, chiefly collected by several German zoologists, has largely been deposited in the Senckenberg Museum, Frankfurt/M., Germany (SMF), with only a few paratypes or duplicates shared with the collections of the Zoological Museum, Moscow State University, Russia (ZMUM), the Natural History Museum of Denmark, Copenhagen, Denmark (ZMUC), and the Northeast Institute of Geography and Agroecology, Chinese Academy of Sciences, Changchun (NEIGAE), as indicated below. The relevant collecting localities shown in Map are referred to in the Material sections as the respective numbers put in square brackets, "[]".

Type material of an old species, kept in the Naturhistorisches Museum Wien (NHMW, Vienna, Austria), has been photographed for comparative purposes.

\section{Taxonomic part}

Oxidus gracilis (C.L. Koch, 1847)

MATERIAL. $60^{7} \sigma^{7}, 11$ 우 (SMF), China, Guangxi Prov., SE of Guilin [1], $1300 \mathrm{~m}$ a.s.1., $110^{\circ} 61263^{\prime} \mathrm{E}, 25^{\circ} 14912^{\prime} \mathrm{N}, 14.06 .2011$, leg. J. Martens; 2 우, 1 juv. (SMF), outskirts of Beijing, near 


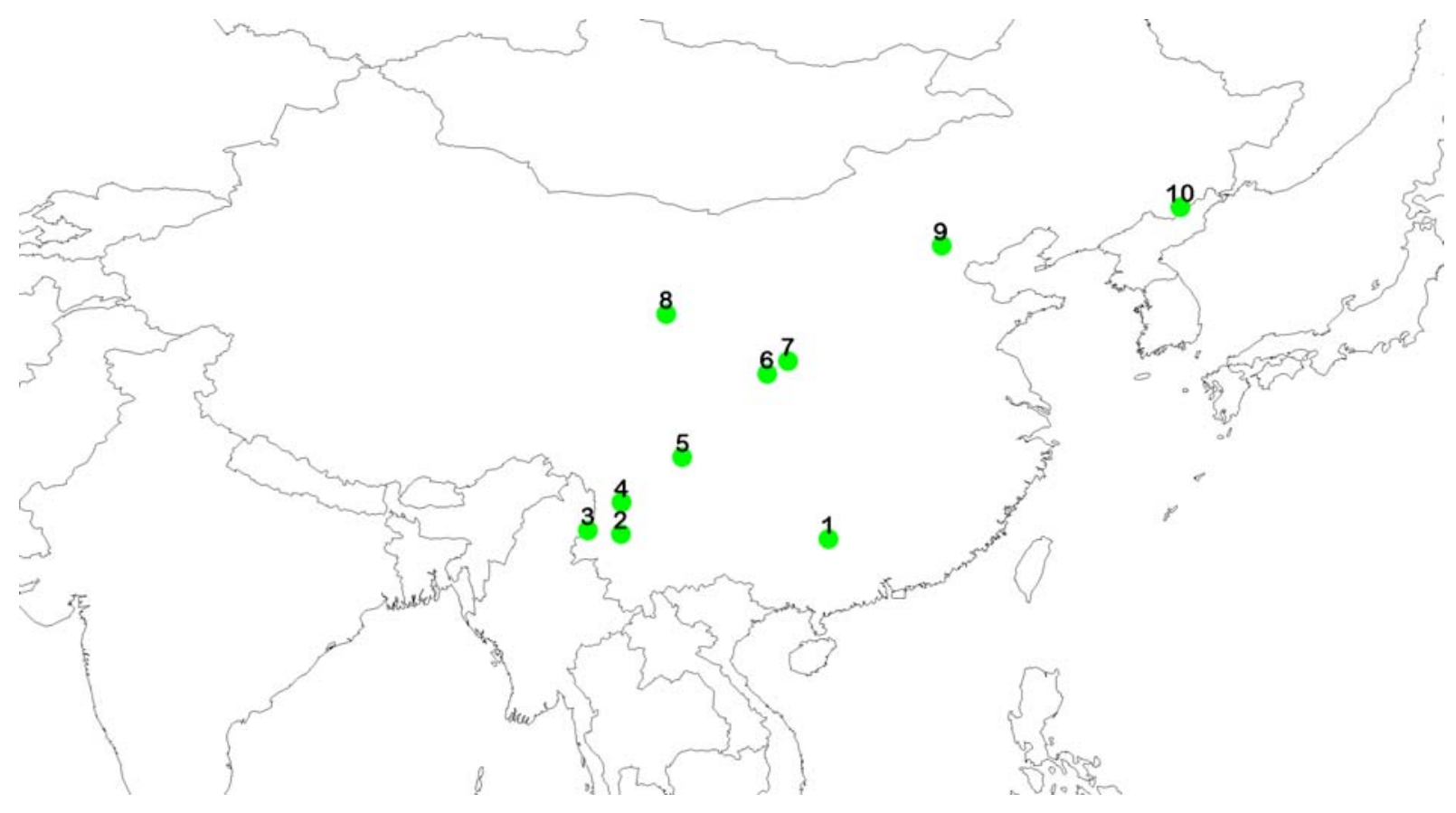

Map. Collecting localities arranged more or less from south to north: 1 - Guilin; 2 - Dali; 3 - Pianma; 4 - Lijiang; 5 - Emei Shan; 6 - Houshenzi; 7 - Xi'an; 8 - Bei Shan; 9 - Beijing International Airport; 10 - Changbai Shan.

Карта. Места сборов, расположенные более или менее с юга на север: 1 - Гуилин; 2 - Дали; 3 - Пианма; 4 - Личжиан; 5 Эмеи-Шань; 6 - Хоушензи; 7 - Сиань; 8 - Беи-Шань; 9 - Пекинский международный аэропорт; $10-$ Чанбай-Шань.

Beijing International Airport [9], $116^{\circ} 35^{\prime} \mathrm{E}, 40^{\circ} 05^{\prime} \mathrm{N}, 23.06 .1996$, leg. J. Martens; 1 + (SMF), Shaanxi Prov., Xi’an City [7], $900 \mathrm{~m}$ a.s.1., $108^{\circ} 55^{\prime} \mathrm{E}, 34^{\circ} 16^{\prime} \mathrm{N}, 05.07 .1997$, leg. J. Martens \& P. Jäger.

REMARKS. This subcosmopolitan, definitely anthropochore species is very common all over China, including its southern parts [e.g. Golovatch, 2012].

Cawjeekelia propria (Mikhaljova et Korsós, 2003)

MATERIAL. $3 \sigma^{7} \sigma^{7}, 1$ ( 9 (NEIGAE), $2 \sigma^{7} \sigma^{7}$ (ZMUM), China, Jilin Prov., ca $12-15 \mathrm{~km}$ W of Changbai Shan National Park [10], ca $500 \mathrm{~m}$ a.s.l., mixed Picea, Abies, Quercus, Acer etc. forest, litter, $128^{\circ} 50^{\prime} \mathrm{E}, 42^{\circ} 00^{\prime} \mathrm{N}, 29.05 .2012$, leg. I. Semenyuk \& S. Golovatch.

REMARKS. This species has hitherto been known only from North Korea [Mikhaljova \& Korsós, 2003; Golovatch, 2011]. So its occurrence also in the adjacent parts of northeastern China, i.e. the Changbai Shan Mountains lying at the border between China and North Korea, is quite normal. Formally, this species is new to the millipede fauna of China.

\section{Kronopolites swinhoei (Pocock, 1895)}

Figs 1-4.

MATERIAL. $2 \sigma^{7} \sigma^{\top}, 1+$ (SMF), China, Shaanxi Prov., Taibai Shan Mts, S slopes, above Houshenzi [6], 107 $50^{\prime} \mathrm{E}, 33^{\circ} 51^{\prime} \mathrm{N}$, secondary broadleaved forest, 1300-1700 m a.s.l., 01.07.1997, leg. J. Martens \& P. Jäger; $1 \sigma^{7}$ (SMF), same locality, 18.06.1977, leg. P.

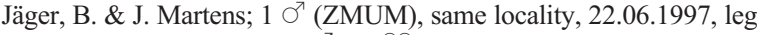
J. Martens \& P. Jäger; $1 O^{7}, 4$ 우, 1 juv. (SMF), same locality, 02.07.1997, leg. J. Martens \& P. Jäger; 1 O , 3 juv. (SMF), same

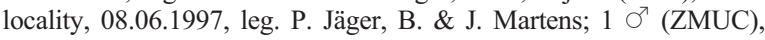

same locality, 09.06.1997, leg. P. Jäger, B. \& J. Martens; $2 O^{7} O^{7}, 1$ ㅇ (SMF), same locality, 19.06.1997, leg. J. Martens \& P. Jäger; $1 O^{3}, 1$ \% (SMF), same locality, 03.07.1997, leg. J. Martens \& P. Jäger; 4 O $^{7} \sigma^{7}, 1$ + (SMF), same locality, 07.07.1977, leg. P. Jäger, B. \& J. Martens; 3 $\sigma^{7} \sigma^{7}, 9$ OO (SMF), Qinghai Prov., Bei Shan National Park [8], 120 km $\mathrm{N}$ of Xining, $102^{\circ} 39^{\prime} \mathrm{E}, 36^{\circ} 56^{\prime} \mathrm{N}$, 05.-06.1996, leg. J. Martens.

REMARKS. This species is very common and widespread in many parts of central and southern China (Gansu, Shandong, Zhejiang, Sichuan, Guizhou and Yunnan) [Golovatch, 2009b], but the above are the first formal records in Shaanxi and Qinghai provinces. The main somatic features and characteristic colour pattern are shown in Figs 1-4, based on material from near Houshenzi. It is noteworthy that a stable colour morph seems to inhabit the Bei Shan National Park, with all specimens from there showing a continuous yellow band, not spots, in the caudal third of each metatergum, this band also covering the paraterga.

Hedinomorpha jeekeli (Golovatch, 2009), comb.n. Figs 5-8.

MATERIAL. $2 \sigma^{7} \sigma^{7}, 1$ ( 1 (SMF), China, Shaanxi Prov., Taibai Shan Mts, S slopes, above Houshenzi [6], $107^{\circ} 50^{\prime} \mathrm{E}, 33^{\circ} 51^{\prime} \mathrm{N}$, secondary broadleaved forest, 1300-1700 m a.s.l., 18.06.1997, leg. P. Jäger, B. \& J. Martens; $1 \sigma^{7}$ (SMF), same locality, 03.07.1997, leg. J. Martens \& P. Jäger; 1 o $^{7}$ (ZMUM), same locality, primary broadleaved forest, 1700-2600 m a.s.1., 11.06.1997, leg. P. Jäger, B. \& J. Martens.

REMARKS. This species has originally been described in the genus Streptogonopus Attems, 1914, from Foping Nature Reserve within the same province 

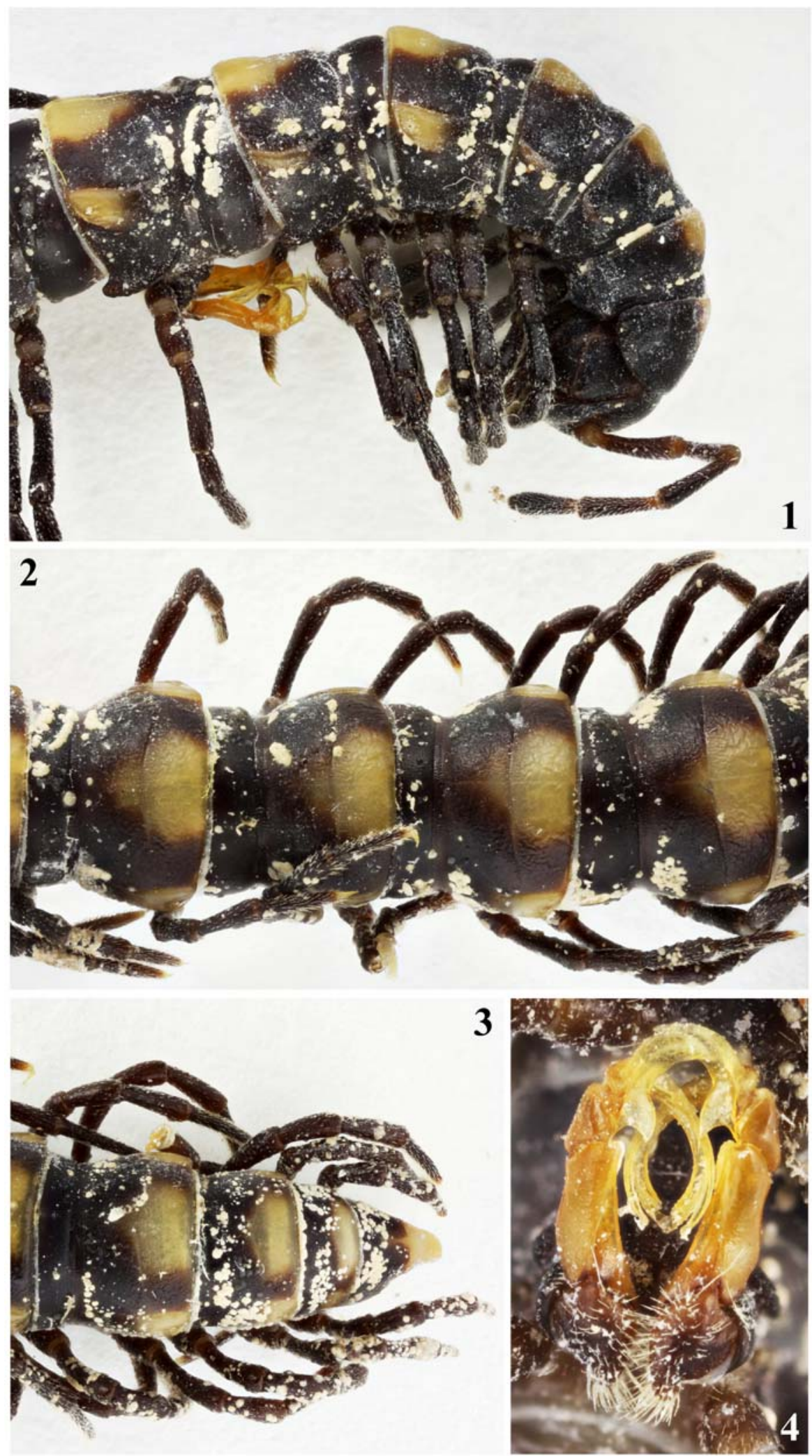

Figs 1-4. Kronopolites swinhoei (Pocock, 1895), $0^{7}$ from above Houshenzi: 1 - anterior part of body, lateral view; 2 - midbody segments, dorsal view; 3 - posterior part of body, dorsal view; 4 - gonopods in situ, ventral view. Photos taken by K. Makarov, not to scale.

Рис. 1-4. Kronopolites swinhoei (Pocock, 1895), О7 из окрестностей Houshenzi: 1 - передняя часть тела, сбоку; 2 среднетуловищные сегменты, сверху; 3 - задняя часть тела, сверху; 4 - гоноподы in situ, снизу. Фото сделаны К. Макаровым, без масштаба. 

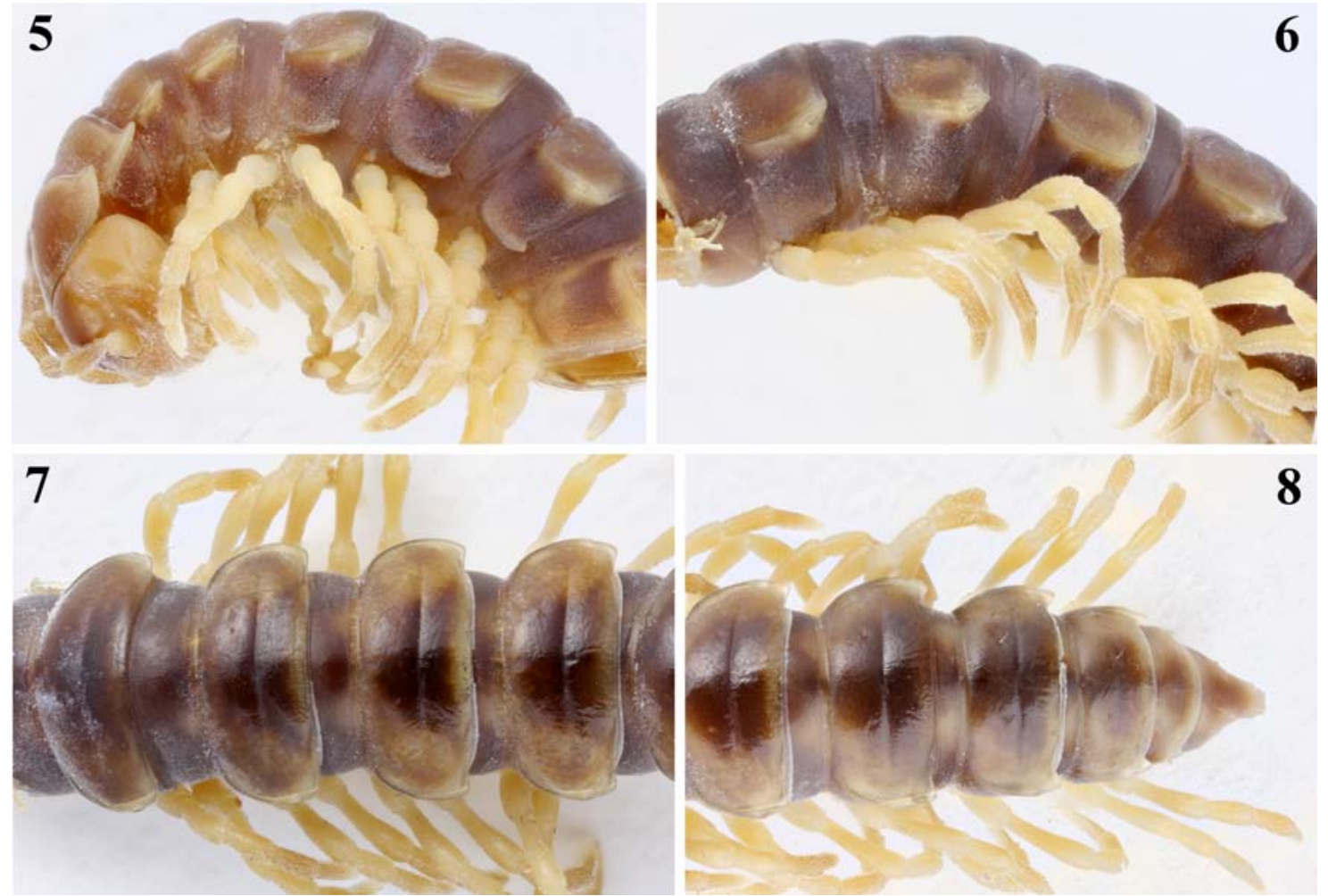

Figs 5-8. Hedinomorpha jeekeli (Golovatch, 2009), O’: 1 - anterior part of body, lateral view; 2 - midbody segments, lateral view; 3 - midbody segments, dorsal view; 4 - posterior part of body, dorsal view. Photos taken by K. Makarov, not to scale.

Рис. 5-8. Hedinomorpha jeekeli (Golovatch, 2009), О: 1 - передняя часть тела, сбоку; 2 - среднетуловищные сегменты, сбоку; 3 - среднетуловищные сегменты, сверху; 4 - задняя часть тела, сверху. Фото сделаны К. Макаровым, без масштаба.
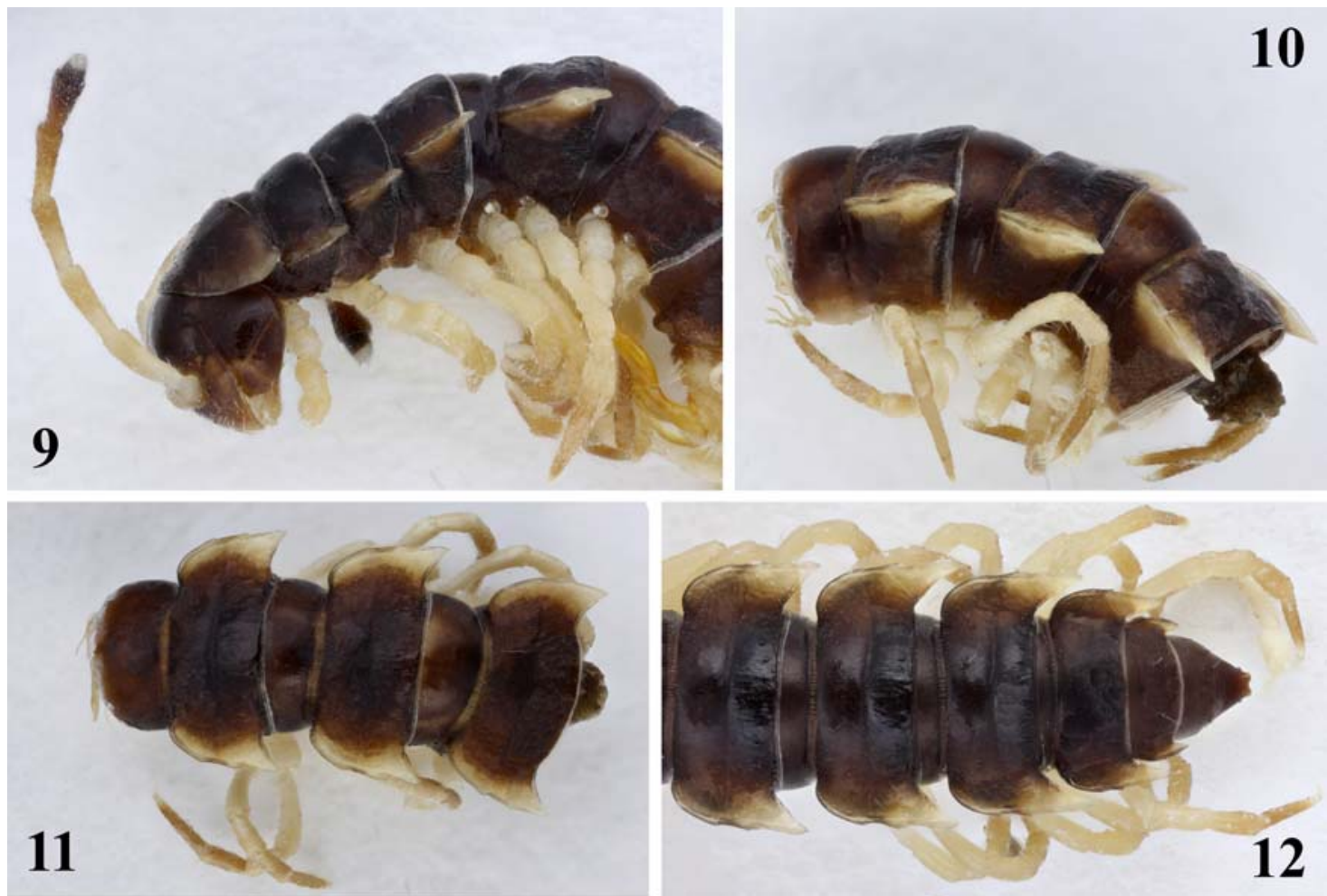

Figs 9-12. Tetracentrosternus hoffmani sp.n., holotype: 9 - anterior part of body, lateral view; 10-11 — midbody segments, lateral and dorsal views, respectively; 12 - posterior part of body, dorsal view. Photos taken by K. Makarov, not to scale.

Рис. 9-12. Tetracentrosternus hoffmani sp.n., голотип: 9 - передняя часть тела; 10-11 — среднетуловищные сегменты, соответственно сбоку и сверху; 12 - задняя часть тела, сверху. Фото сделаны К. Макаровым, без масштаба. 


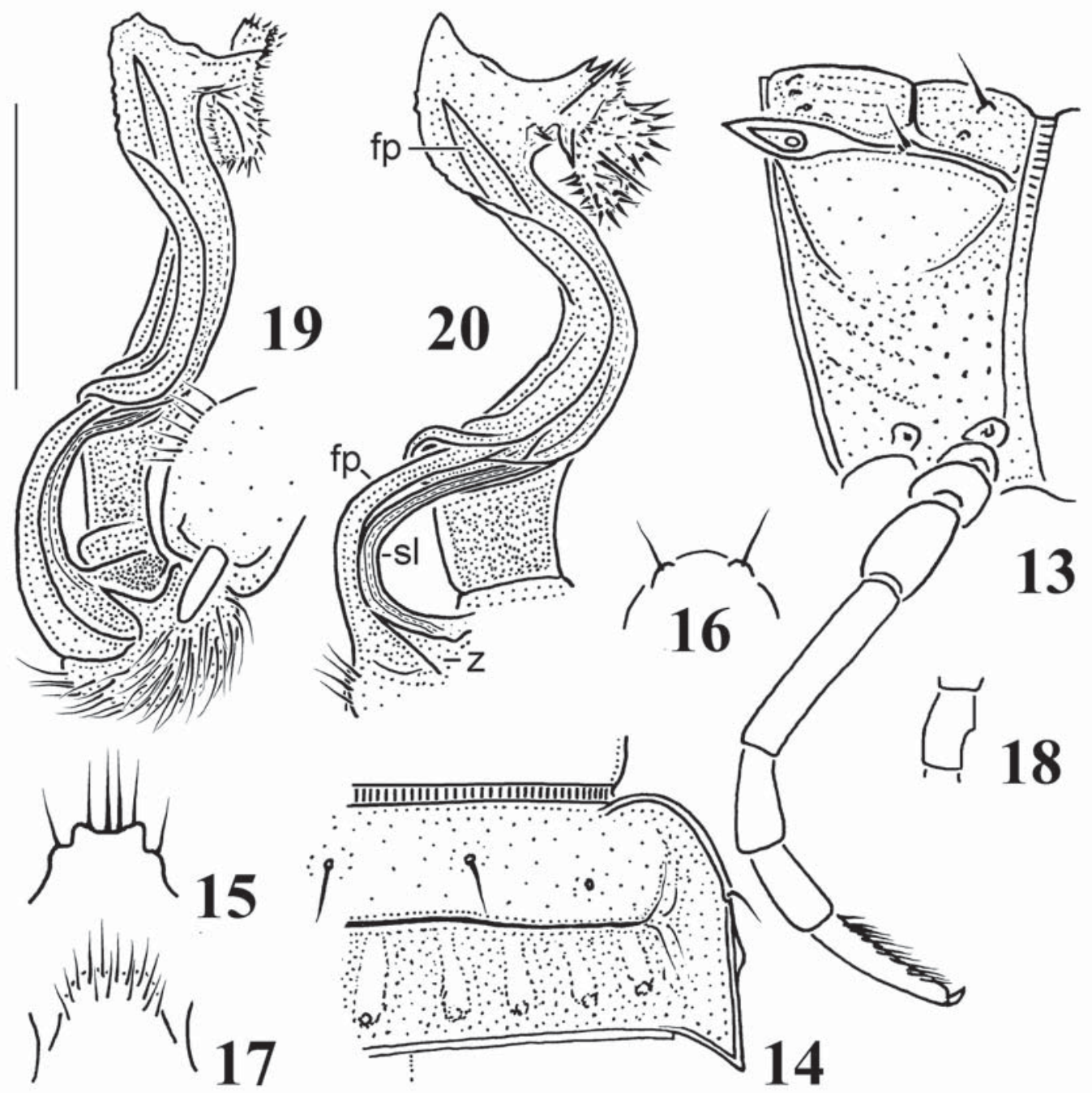

Figs 13-20. Tetracentrosternus hoffmani sp.n., holotype: 13-14 — body segment 10, lateral and dorsal views, respectively; 15 epiproct, dorsal view; 16 - hypoproct, ventral view; 17 - sternal lobe between coxae 4, ventrocaudal view; 18 — femur 1; 19-20 — right gonopod, mesal and subdorsal views, respectively. Scale bar: 1.0 (13-18) and $0.5 \mathrm{~mm}$ (19-20).

Рис. 13-20. Tetracentrosternus hoffmani sp.n., голотип: 13-14 - туловищный сегмент 10, соответственно сбоку и сверху; 15 эпипрокт, вид сбоку; 16 - гипопрокт, вид снизу; 17 - стернальная пластина между тазиками 4, вид одновременно сзади и снизу; 18 - бедро 1; 19-20 — правый гонопод, соответственно изнутри и субдорсально. Масштаб 1,0 (13-18) и 0,5 мм (19-20).

[Golovatch, 2009a]. The new samples fully agree with the original description, the main somatic features and colour pattern being shown in Figs 5-8.

The new combination is warranted because the gonopod conformation actually matches fully that of Hedinomorpha Verhoeff, 1933, as recently redefined by Golovatch [2012]. Furthermore, a new congener (Figs 125-136) described below also appears to be quite similar to $H$. jeekeli.

\section{Tetracentrosternus hoffmani sp.n.}

Figs 9-20.

HOLOTYPE $\sigma^{\top}$ (SMF), China, Yunnan Prov., Gaoligong Shan Mts, S of Pianma [3], $98^{\circ} 40^{\prime} \mathrm{E}, 25^{\circ} 58^{\prime} \mathrm{N}, 1610 \mathrm{~m}$ a.s.1., 06.06.2011, leg. J. Martens.
NAME. Honours the late Richard L. Hoffman, an outstanding friend and specialist in diplopod taxonomy.

DIAGNOSIS. Differs from T. subspinosus Pocock, 1895, the type, and only other known, species of the genus, from Myanmar [Hoffman, 1963; Jeekel, 1965], by the considerably more strongly developed paraterga (Figs 9-14), the absence of sternal cones, and the presence of a distinct, basal, mesal, gonofemoral tooth (z) (Figs 19 \& 20).

DESCRIPTION. Length ca $19 \mathrm{~mm}$, width of midbody pro- and metazona 1.7 and $2.0 \mathrm{~mm}$, respectively. General coloration in alcohol blackish brown to dark brown; antennomeres 1-6, legs and caudal halves of paraterga light grey-brown.

In width, head $=$ collum $=$ segments 2 and $3<4<$ 5-17; thereafter body gradually tapering towards telson. 

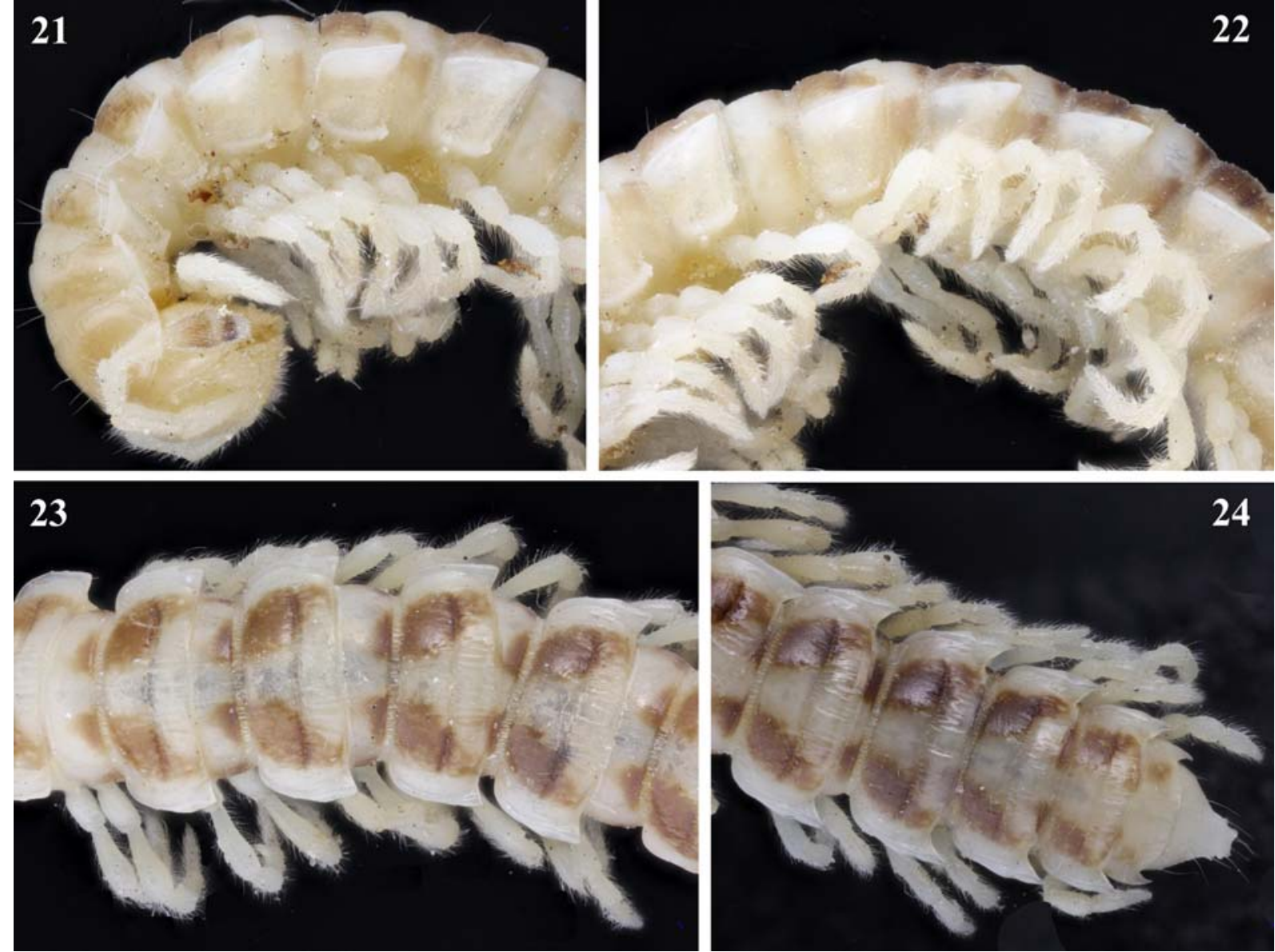

Figs 21-24. Tylopus schawalleri sp.n., holotype: 21 - anterior part of body, lateral view; 22-23 - midbody segments, lateral and dorsal views, respectively; 24 - posterior part of body, dorsal view. Photos taken by K. Makarov, not to scale.

Рис. 21-24. Tylopus schawalleri sp.n., голотип: 21 - передняя часть тела; 22-23 - среднетуловищные сегменты, соответственно сбоку и сверху; 24 - задняя часть тела, сверху. Фото сделаны К. Макаровым, без масштаба.

Clypeolabral region densely, vertigial region sparsely, setose. Antennae rather slender and long, reaching behind body segment 3 when stretched dorsally $\left(\sigma^{T}\right)$; antennomere $2=3=4$, each only slightly longer than subequal $5^{\text {th }}$ and $6^{\text {th }}$. Paraterga rather strongly developed (Figs 9-14), subhorizontal, invariably broadly rounded frontally, set high, mostly lying at about $1 / 4^{\text {th }}$ of midbody height; paraterga 2 particularly low, a distinct, large, broadly rounded lobe not produced caudad beyond rear margin; following paraterga increasingly strongly beak-shaped and pointed, paraterga 3 and 4 still lying within, subsequent ones until $19^{\text {th }}$ increasingly well produced behind, rear tergal margin, about $1 / 3$ of metazonital length in segments 15 and 16, nearly entire metazonital length in segments 17 and 18. Paraterga thin, keel-shaped, with a small, often setigerous denticle near anterior third, only a little thicker subcaudally in pore-bearing segments compared to poreless ones; calluses very thin, delimited by a weak sulcus only dorsally. Ozopores lateral, mostly lying inside an ovoid groove slightly in front of caudal margin (Figs 9, 10 \& 13). Body surface mostly smooth and modestly shining, postsulcus halves of metaterga longitudinally rugose to rugulose, sides below paraterga rugulose and microgranulate. Axial line missing. Transverse metatergal sulcus thin and incomplete in segment 4, broader, complete, reaching bases of paraterga, deep, but smooth at bottom in segments $5-18$, absent from $19^{\text {th }}$. Tergal setae rather long (ca $1 / 4^{\text {th }}$ of metatergal length), often abraded, arranged in three transverse rows of about $4+4,2+2$ and $3+3$ on collum, in two transverse rows of $2+2$ in front of and $4+4$ behind sulcus on following metaterga, pattern traceable due to small knobs and/or small oblong ridges (Figs $13 \& 14$ ). Stricture dividing pro- and metazona rather narrow, deep, finely and densely ribbed down to about level of paraterga (Figs 13 \& 14). Pleurosternal carinae evident, granulate, rounded, subcaudal teeth present only in segments 2-7, onward missing. Epiproct (Figs 12 \& 15) rather short, flattened dorsoventrally, tip evidently concave between large apical papillae, subapical papillae smaller, but also evident. Hypoproct (Fig. 16) semi-circular, caudal 1+1 setae clearly separated and borne on minute knobs.

Sternites without modifications, densely setose; cross-impressions rather modest, especially axial one; a high, roundly subtrapeziform, setose lamina between 


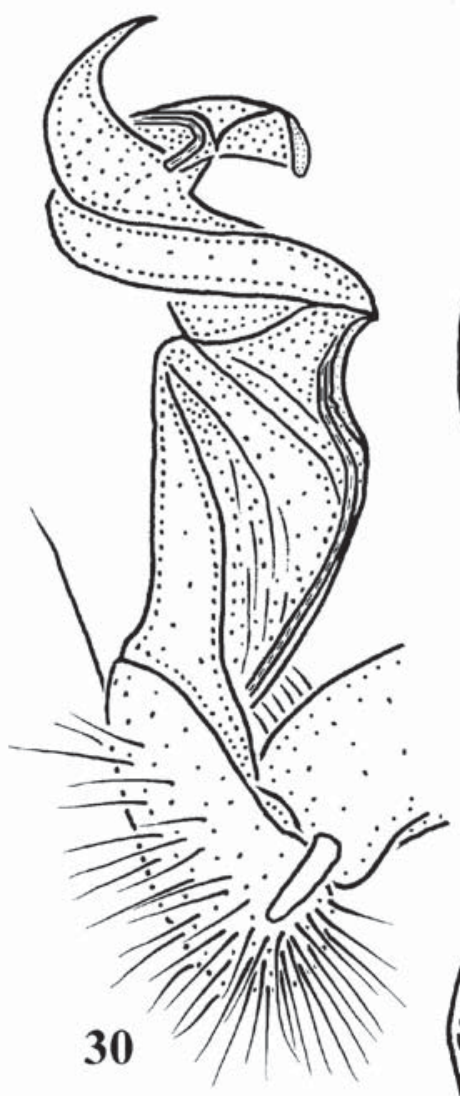

Figs 25-31. Tylopus schawalleri sp.n., holotype: 25-26 - body segment 10, lateral and dorsal views, respectively; 27 - epiproct, dorsal view; 28 - hypoproct, ventral view; 29 - sternal lobe between coxae 4, ventrocaudal view; 30-31 - right gonopod, mesal and lateral views, respectively. Scale bar: 1.0 (25-29) and $0.5 \mathrm{~mm}(30-31)$.

Рис. 25-31. Tylopus schawalleri sp.n., голотип: 25-26 - туловищный сегмент 10, соответственно сбоку и сверху; 27 эпипрокт, вид сверху; 28 - гипопрокт, вид снизу; 29 - стернальная пластина между тазиками 4, вид одновременно сзади и снизу; 30-31 - правый гонопод, соответственно изнутри и сбоку. Масштаб 1,0 (25-29) и 0,5 мм (30-31).

$\sigma^{7}$ coxae 4 (Fig. 17). Legs long and slender (Figs 913), ca 2.0 times as long as midbody height $\left(O^{7}\right)$; prefemora without evident dorsal bulges; ventral brushes especially dense in tarsi $1-7$, present, but gradually thinning out towards midbody tarsi. Femur 1 with a weak, but evident adenostyle in basal third (Fig. 18).

Gonopods (Figs 19 \& 20) complex; coxite rather short, subcylindrical, setose ventrally; prefemoral part as usual, densely setose, rather short, about 4 times shorther than acropodite; femorite rudimentary, nearly missing, mesally with a strong tooth $(\mathbf{z})$, a very long, spiniform, femoral process (fp) and a similarly long, flagelliform solenomere (sl) branching off distodorsally, both latter to become sheathed mesally at about basal third by a folded, slightly sinuate, distally expanded and strongly shaggy solenophore.

REMARKS. Tetracentrosternus Pocock, 1895 has hitherto remained monotypic, being considered as one of the few genera composing the small Oriental tribe Alogolykini [Hoffman, 1963, 1980; Jeekel, 1965, 1968].
The new species slightly extends the known generic diagnosis through showing considerably more strongly developed paraterga, no sternal cones, and an additional gonofemoral tooth (Figs $19 \& 20, \mathbf{z}$ ). In any event, this new species readily keys out as a Tetracentrosternus, using the latest available key [Jeekel, 1965].

\section{Tylopus schawalleri sp.n.}

Figs 21-31.

HOLOTYPE $0^{7}$ (SMF), China, Yunnan Prov., Diancang Shan Mts, above Dali [2], $100^{\circ} 06^{\prime} \mathrm{E}, 25^{\circ} 41^{\prime} \mathrm{N}, 2500-2700 \mathrm{~m}$ a.s.1., 18.04.1999, leg. W. Schawaller.

NAME. Honours Wolfgang Schawaller, my good friend and the collector.

DIAGNOSIS. Differs from known congeners by the peculiar colour pattern, combined with the rather simple leg and gonopod structure, especially the twisted and large solenophore process $\mathbf{h}$ [Likhitrakarn et al., 2010]. 

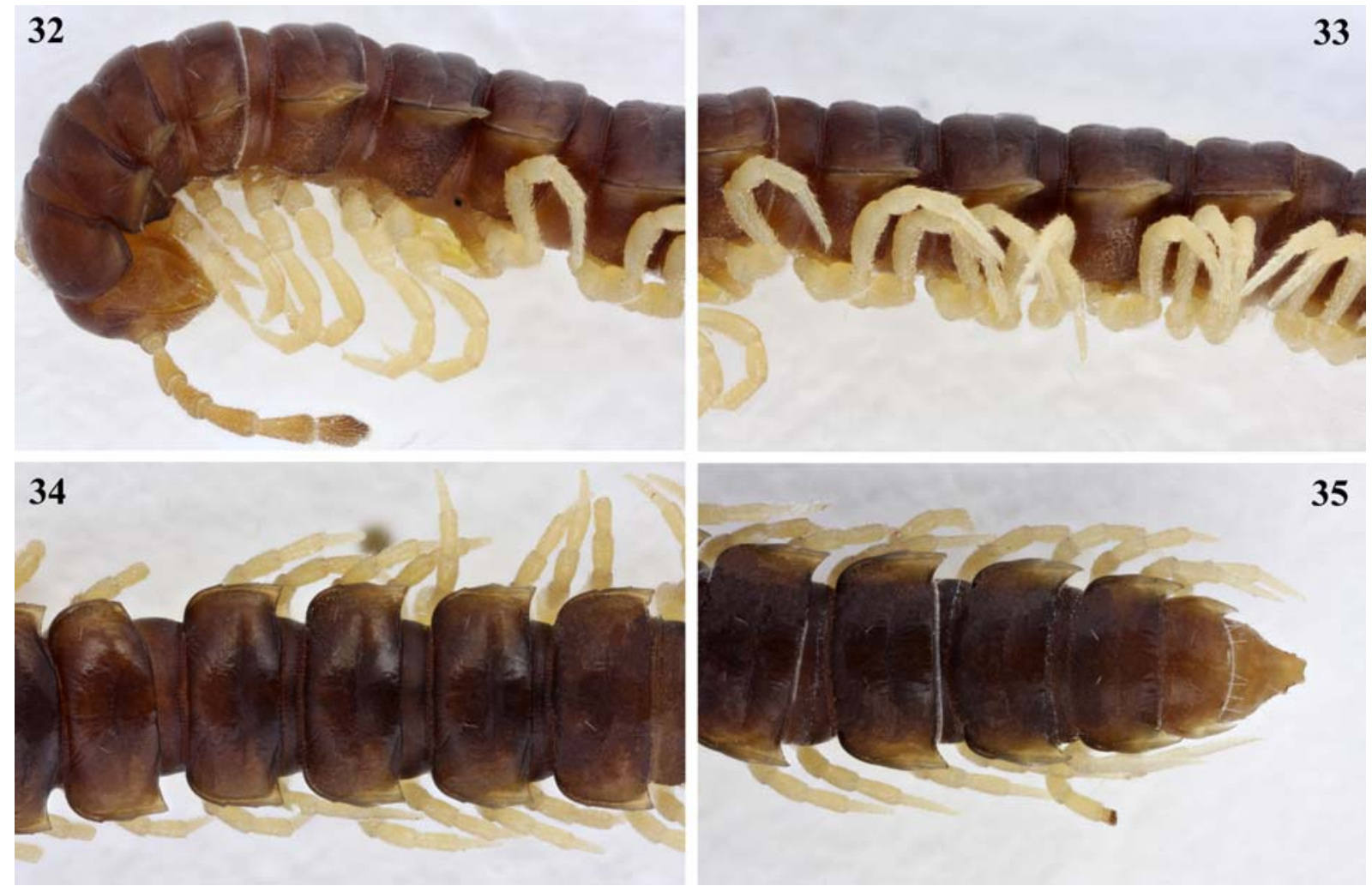

Figs 32-35. Tylopus reductus sp.n., $\mathrm{O}^{7}$ paratype: 32 - anterior part of body, lateral view; 33-34 - midbody segments, lateral and dorsal views, respectively; 35 - posterior part of body, dorsal view. Photos taken by K. Makarov, not to scale.

Рис. 32-35. Tylopus reductus sp.n., паратип O’: 32 - передняя часть тела; 33-34 - среднетуловищные сегменты, соответственно сбоку и сверху; 35 - задняя часть тела, сверху. Фото сделаны К. Макаровым, без масштаба.

DESCRIPTION. Length ca $17 \mathrm{~mm}$, width of midbody pro- and metazona 1.8 and $2.0 \mathrm{~mm}$, respectively. General coloration in alcohol rather uniformly whitish grey with a light brown pattern; antennomere 6 light brown, antennomere 7 blackish brown; pattern: $1+1$ small, paramedian, light brown spots on proterga in front of stricture fusing to similar, but larger spots at bases of paraterga, leaving a wide, light, subtriangular, axial spot on metaterga (Figs 21-26).

In width, head $=$ segment $3<$ collum $=$ segments 2 and $4<5-16$; thereafter body gradually tapering towards telson. Clypeolabral region densely setose, vertigial region with a few setae only. Antennae slender and rather long, extending behind metatergum 3 when stretched dorsally $\left(\mathrm{O}^{7}\right)$, antennomeres 2-6 subequal in length. Paraterga rather poorly developed (Figs 21-26), set low, mostly lying at about $1 / 3-1 / 2$ of midbody height, extending increasingly well behind rear tergal margin in segments 2 (broadly rounded) and 7-19 (beak-shaped and pointed, same as in paraterga 3-6). Paraterga slightly declined to subhorizontal, thin keels slightly thicker subcaudally in pore-bearing segments compared to poreless ones, each delimited by a thin sulcus both dorsally and ventrally, always broadly rounded anteriorly, each with a faint denticle at about front third. Ozopores lateral, placed inside an ovoid groove, lying slightly in front of caudal margin, only in segments
17-19 shifted increasingly close to the margin. Body surface mostly rather smooth and shining, front halves of metaterga mostly rugulose, caudal halves of metaterga longitudinally rugose, especially so close to sulcus; sides striolate and microgranulate. Axial line present on postcollum metaterga (Figs 23, 24 \& 26). Transverse metatergal sulcus evident in segments 5-18, rather deep and finely striate at bottom, reaching bases of paraterga. Tergal setae mostly abraded, rather long, pattern usually traceable as insertion points arranged in three transverse rows of about $4+4,2+2$ and $2+2$ on collum and in one row of $2+2$ setae in front of sulcus on following metaterga (Figs $25 \& 26$ ). Stricture dividing pro- and metazona finely, but clearly ribbed or striate down to below paraterga. Pleurosternal carinae complete and increasingly well developed in segments 2-7, abruptly reduced, but still complete ribs in segments 8 and 9, poorly developed caudal bulges in segments 10 and 11 (Figs 21, $22 \& 25)$, thereafter missing $\left(\sigma^{7}\right)$. Epiproct (Figs 24 \& 27) rather short, flattened dorsoventrally, tip narrowly concave due to large apical papillae, subapical papillae evident. Hypoproct (Fig. 28) high, roundly subtrapeziform, caudal $1+1$ setae rather strongly separated, not borne on evident knobs.

Sternites without modifications, rather densely setose, cross-impressions usual, rather evident; a long, 


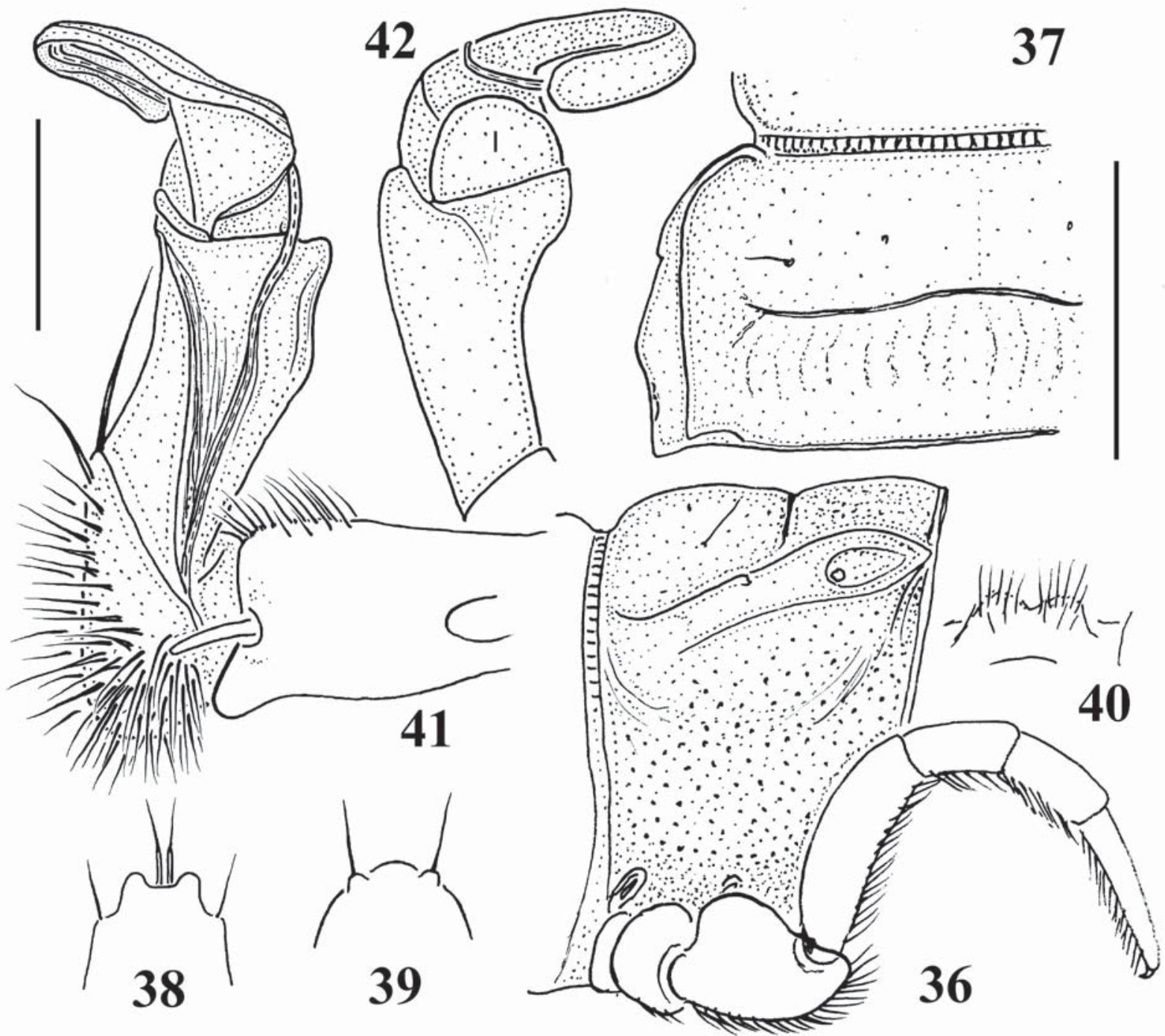

Figs 36-42. Tylopus reductus sp.n., $0^{7}$ paratype: 36-37 — body segment 10, lateral and dorsal views, respectively; 38 - epiproct, dorsal view; 39 - hypoproct, ventral view; 40 - sternal lobe between coxae 4, ventrocaudal view; 41-42 - right gonopod, mesal and lateral views, respectively. Scale bars: $1.0(36-40)$ and $0.3 \mathrm{~mm}(41-42)$.

Рис. 36-42. Tylopus reductus sp.n., паратип О7: 36-37 - туловищный сегмент 10, соответственно сбоку-сверху; $38-$ эпипрокт, вид сверху; 39 - гипопрокт, вид снизу; 40 - стернальная пластина между тазиками 4, вид одновременно сзади и снизу; 41-42 - правый гонопод, соответственно изнутри и сбоку. Масштаб 1,0 (36-40) и 0,3 мм (41-42).

rounded, densely setose, linguiform lamina between coxae 4 (Fig. 29). Legs (Figs 21-25) probably incrassate, rather short, ca 1.2 times as long as midbody height $\left(\sigma^{7}\right)$; prefemora normal, without evident dorsal bulges; ventral brushes present in tarsi until a few last leg-pairs; adenostyles absent.

Gonopods (Figs 30 \& 31) rather simple; femorite rather stout, expanded distad, showing a mesal groove, but no other distal outgrowths except lobe l; solenophore long and slender, typically coiled, tip subtruncate; process $\mathbf{h}$ high, strongly twisted, pointed apically.

REMARKS. Tylopus Jeekel, 1968 is certainly one of the most speciose genera of the tribe Sulciferini confined to southeastern Asia and southern China [Likhitrakarn et al., 2010]. It currently encompasses already 44 species which are restricted to Myanmar (2 species), Thailand (26 species), Laos (2 species), Vietnam (13 species) and southern China (4 species, including both new ones described herein). In general, all four Chinese Tylopus species tend to show quite simple gonopods totally devoid of femoral and of most or even all of the solenophore outgrowths so characteristic of numerous congeners from Thailand, Myanmar or Vietnam [Golovatch \& Enghoff, 1993; Likhitrakarn et al., 2010].

\section{Tylopus reductus sp.n.}

Figs 32-42.

HOLOTYPE $0^{\top}$ (SMF), China, Yunnan Prov., Gaoligong Shan Mts, $\mathrm{S}$ of Pianma [3], $98^{\circ} 40^{\prime} \mathrm{E}, 25^{\circ} 58^{\prime} \mathrm{N}, 1600-1800 \mathrm{~m}$ a.s.l., 04.06.2011, leg. J. Martens. 

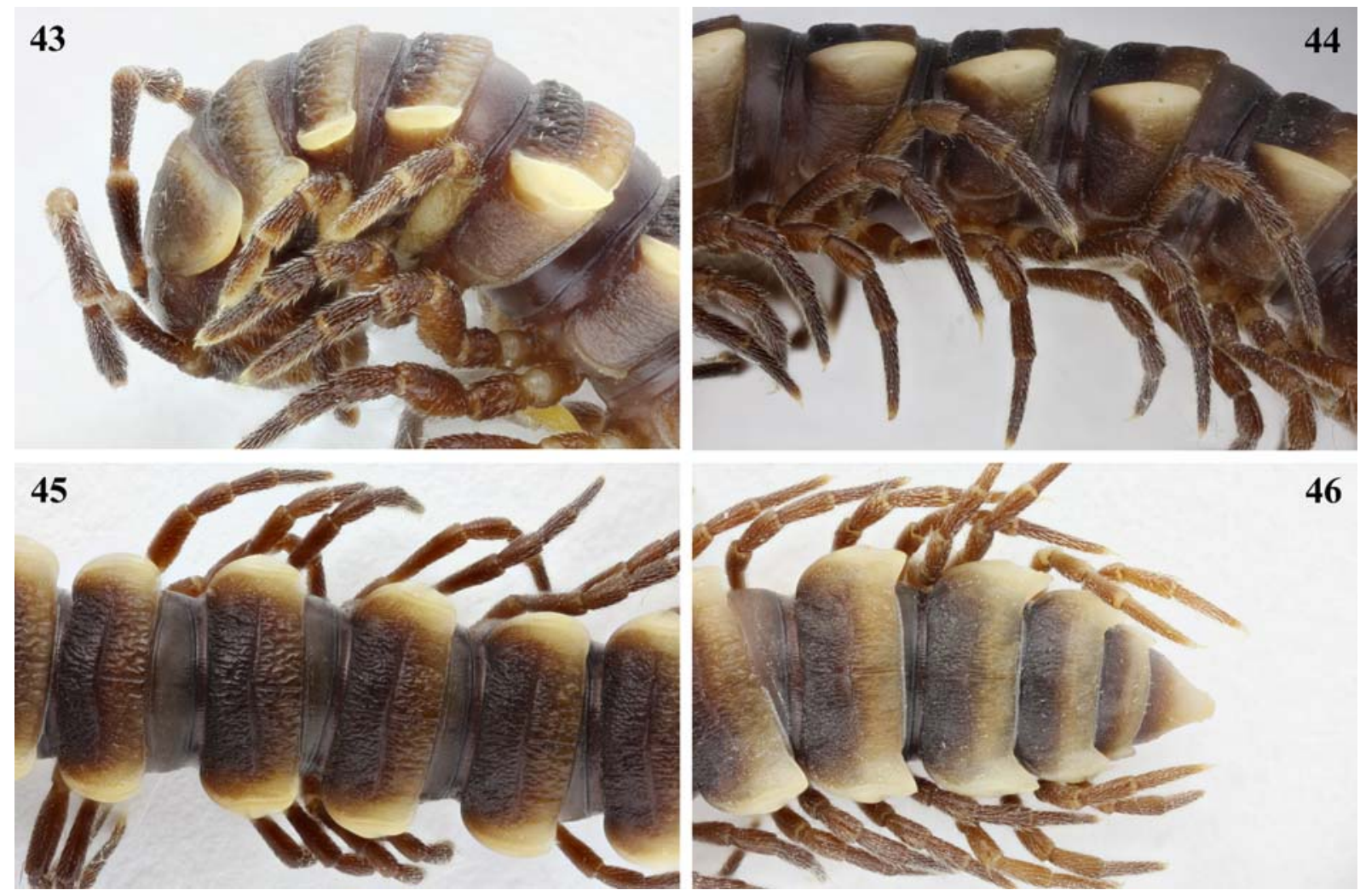

Figs 43-46. Kronopolites rugosus sp.n., holotype: 43 - anterior part of body, lateral view; 44-45 - midbody segments, lateral and dorsal views, respectively; 46 - posterior part of body, dorsal view. Photos taken by K. Makarov, not to scale.

Рис. 43-46. Kronopolites rugosus sp.n., паратип o’: 43 - передняя часть тела; 44-45 - среднетуловищные сегменты, соответственно сбоку и сверху; 46 - задняя часть тела, сверху. Фото сделаны К. Макаровым, без масштаба.

PARATYPES: $1 \sigma^{\pi}, 1 \sigma^{\Upsilon}$ (fragment, rear half of body), 4 + (SMF), $1 \sigma^{\top}, 1$ ㅇ (ZMUM), same data, together with holotype.

NAME. To emphasize perhaps the most reductionist condition of gonopod conformation hitherto observed in Tylopus, including the totally suppressed process $\mathbf{h}$ of the solenophore.

DIAGNOSIS. Differs from all known congeners except T. strongylosomoides (Korsós \& Golovatch, 1989), from northern Vietnam [cf. Korsós \& Golovatch, 1989], in the completely reduced solenophore process $\mathbf{h}$, from $T$. strongylosomoides by the considerably more strongly developed paraterga, the rugose/rugulose postsulcus halves of metaterga, the missing $\sigma^{7}$ leg adenostyles, and the much less strongly coiled and elaborate solenophore.

DESCRIPTION. Length ca $19\left(\sigma^{7}\right)$ or $20-21 \mathrm{~mm}$ $(+)$, width of midbody pro- and metazona 1.8 and 2.0 $\mathrm{mm}\left(\sigma^{7}\right)$, or $2.1-2.2$ and $2.5-2.6 \mathrm{~mm}(+)$, respectively. General coloration in alcohol rather uniformly light to dark brown, anterior part of body somewhat infuscate, rear halves of paraterga slightly lighter than background, only venter and legs whitish grey to light brown (Figs 32-35).

In width, head $<$ collum $<$ segments 2 and $3<$ segment $4<5-16 / 17\left(\sigma^{7}\right)$, or head $=$ collum $=$ segments 3 and $4<$ segment $2<5-16$; thereafter body gradually tapering towards telson. Clypeolabral region densely setose, vertigial region with a few setae only. Antennae slender and rather long, extending behind metatergum $2\left(O^{7},+\right)$ when stretched dorsally; antennomeres 2-6 subequal in length. Paraterga rather poorly developed (Figs 32-37), set relatively high, mostly lying at about 1/3-1/4 of midbody height; caudal corner mostly lying within tergal contour, slightly extended beyond the contour starting from segment 15 , extended increasingly well behind tergal margin and triangular only in segments 16-18, shorter and spiniform in segment 19. Paraterga slightly declined to subhorizontal, collum broadly and regularly rounded laterally, paraterga 2 rather narrowly rounded caudally, thereafter mostly narrowly rounded, (nearly) pointed and beak-shaped; thin keels slightly thicker in caudal part in pore-bearing segments compared to poreless ones; each callus delimited by a deep sulcus dorsally, by another, somewhat less deep sulcus in rear $2 / 3^{\text {rds }}$ ventrally; calluses always broadly rounded anteriorly, each with one faint denticle at about front one-third in porebearing segments, with two similar denticles at about each third in poreless segments. Ozopores lateral, placed inside an ovoid groove, lying at about caudal quarter of metatergite's length, only in segments 17-19 shifted increasingly close to caudal margin. Body surface 


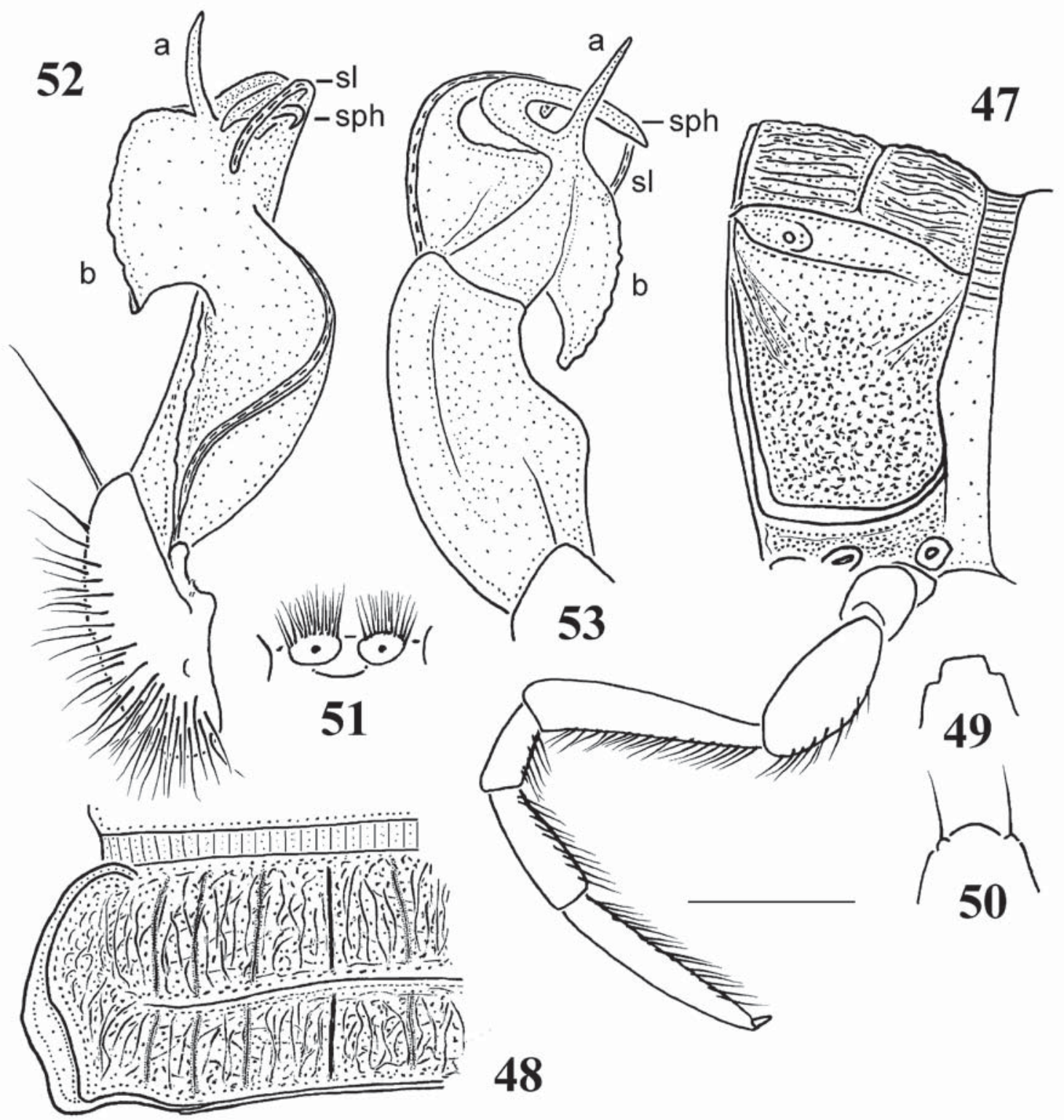

Figs 47-53. Kronopolites rugosus sp.n., holotype: 47-48 - body segment 10, lateral and dorsal views, respectively; 49 - epiproct, dorsal view; 50 - hypoproct, ventral view; 51 - sternal cones between coxae 4, ventrocaudal view; 52-53 - right gonopod, mesal and lateral views, respectively. Scale bars: $1.0(47-51)$ and $0.5 \mathrm{~mm}(52-53)$.

Рис. 47-53. Kronopolites rugosus sp.n., голотип: 47-48 - туловищный сегмент 10, соответственно сбоку-сверху; 49 эпипрокт, вид сверху; 50 - гипопрокт, вид снизу; 51 - стернальные бугорки между тазиками 4, вид одновременно сзади и снизу; 52-53 - правый гонопод, соответственно изнутри и сбоку. Масштаб 1,0 (47-51) и 0,5 мм (52-53).

shining, front halves of metaterga mostly smooth to rugulose, caudal halves of metaterga longitudinally rugose, especially so close to transverse sulcus; sides striolate and microgranulate. Axial line sometimes poorly traceable on postcollum metaterga. Transverse metatergal sulcus evident, complete and reaching bases of paraterga in segments $4-18$, rather deep and smooth at bottom. Tergal setae mostly abraded, rather short (ca $1 / 5^{\text {th }}$ of metatergal length), pattern mostly traceable as discernible insertion points arranged in three transverse rows on collum, in one row of $2+2$ setae in front of sulcus and in another row of $4+4$ setae near caudal margin on following metaterga, the caudal row at least partly being retained only on metaterga 18 and 19 . Stricture dividing pro- and metazona finely, but evidently ribbed or striate down to below paraterga (Figs 36 \& 37). Pleurosternal carinae complete and supplied with a caudal denticle in segments 2-14 (Figs 32 \& 33), complete, but devoid of a caudal denticle until segment 18 , missing on $19^{\text {th }}$, or traceable as poorly developed caudal denticles only until segment $10(+)$. Epiproct (Figs 35 \& 38) rather short, flattened 
dorsoventrally, tip emarginate between large apical papillae, subapical papillae small, but evident. Hypoproct (Fig. 39) semi-circular, caudal 1+1 setae strongly separated, borne on small knobs.

Sternites without modifications, densely setose, cross-impressions shallow; a low, bisinuate, densely setose lamina between $\sigma^{7}$ coxae 4 (Fig. 40). Legs (Figs 32-36) rather densely setose, slightly incrassate in $\sigma^{7}$, thinner in + , rather long, ca $1.5\left(\sigma^{7}\right)$ or $1.1-1.2$ times $(+)$ as long as midbody height $\left(\sigma^{7}\right)$; $\sigma^{7}$ prefemora with evident lateral bulges; ventral brushes absent, only $\sigma^{7}$ tarsi 1-5 somewhat brush-like setose ventrally, thereafter gradually thinning out; adenostyles absent.

Gonopods (Figs 41 \& 42) very simple; femorite rather stout, slightly expanded distad, showing a mesal groove, but no other distal outgrowths except lobe $\mathbf{l}$; solenophore long and slender, typically coiled, devoid of processes.

REMARKS. All four species of Tylopus currently known from China [Golovatch, 1995; Liu \& Luo, 2013] can easily be separated, using the following key.

1(2) Paraterga never beak-shaped caudally. Transverse sulcus not reaching bases of paraterga. Process $\mathbf{h}$ of solenophore a small round lobe. ........................... T. sinensis

2(1) At least some paraterga pointed and beak-shaped caudally. Transverse sulcus mostly reaching bases of paraterga. Process $\mathbf{h}$, when present, either spiniform or ribbonshaped, elongate and twisted.

3(4) $O^{7}$ podomeres with ventral tuberculations. Process $\mathbf{h}$ of solenophore an evident spine. Guangxi.

T. deharvengi

4(3) ) $\sigma^{T}$ podomeres without ventral tuberculations. Process h of solenophore absent or long. Yunnan. .................. 5

5(6) Metaterga less strongly rugose-rugulose (Figs 34-37). $\sigma^{7}$ femora evidently swollen dorsally (Fig. 36). Process h of solenophore absent (Figs $40 \& 41$ ).

T. reductus sp.n.

6(5) Metaterga more strongly rugose-rugulose (Figs 23-26) $\sigma^{7}$ femora not swollen dorsally (Fig. 25). Process h of solenophore long (Figs 30 \& 31)... T. schawalleri sp.n.

\section{Kronopolites rugosus sp.n.}

Figs 43-53.

HOLOTYPE $0^{7}$ (SMF), China, Yunnan Prov., N of Lijiang [4], $100^{\circ} 12^{\prime} \mathrm{E}, 27^{\circ} 01^{\prime} \mathrm{N}, 2400 \mathrm{~m}$ a.s.1., 12.04.1999, leg. W. Schawaller.

NAME. To emphasize the rugose to rugulose metaterga.

DIAGNOSIS. Differs from all known congeners by the rugose to rugulose metaterga, coupled with the peculiar shapes of processes $\mathbf{a}$ and $\mathbf{b}$ of the solenophore.

DESCRIPTION. Length ca $26 \mathrm{~mm}$, width of midbody pro- and metazona 2.7 and $3.9 \mathrm{~mm}$, respectively. General coloration in alcohol mostly dark brown; rear halves of metaterga somewhat lighter, yellow-brown; antennae, legs, front halves of metaterga, sides and head dark brown; rear $2 / 3^{\text {rds }}$ of paraterga contrasting yellow (Figs 43-46).

In width, head $<$ collum $=$ segments 3 and $4<2<$ $5-16$; thereafter body gradually tapering towards tel- son. Entire head very densely setose. Antennae slender and rather long, extending behind metatergum 3 when stretched dorsally $\left(\sigma^{7}\right)$. Paraterga modestly developed (Figs 43-48), set rather high, mostly lying at about 1/3$1 / 4$ of midbody height; caudal corner largely broadly rounded and lying within rear tergal margin until segment 14, thereafter subtriangular, extended increasingly well behind the margin, nearly pointed and beakshaped in segments 15-19. Paraterga slightly declined to subhorizontal, evident keels slightly thicker in porebearing segments compared to poreless ones, each delimited by a thin sulcus both dorsally and ventrally, always broadly rounded anteriorly. Ozopores lateral, placed inside an ovoid groove, lying slightly in front of caudal margin, only in segments 17-19 shifted increasingly close to the margin. Body surface mostly rugoserugulose, dull; surface below paraterga striolate/rugulose and microgranulate. Axial line present on postcollum metaterga (Figs 45, 46 \& 48). Transverse metatergal sulcus evident in segments 4-18, rather deep and smooth at bottom, reaching bases of paraterga. Tergal setae mostly abraded, rather short (ca $1 / 5^{\text {th }}$ of metatergite's length, same as on head), pattern often traceable as discernible insertion points arranged in four transverse, rather irregular rows on collum (ca $8+8,3+3$, $4+4$ and 4+4) and in two transverse, more regular rows on following metaterga: one of $4+4$ or $5+5$ setae in front of, the other of $5+5$ ones behind, the sulcus. Stricture dividing pro- and metazona finely, but evidently ribbed or striate down to below paraterga (Figs 47 \& 48). Pleurosternal carinae (Figs 43, 44 \& 47) complete and supplied with a caudal denticle in segments 2-14, also complete low ribs devoid of a caudal denticle in segments 15-18, absent from $19^{\text {th }}\left(\sigma^{7}\right)$. Epiproct (Figs 46 \& 49) rather short, flattened dorsoventrally, tip subtruncate, subapical papillae small, but evident. Hypoproct (Fig. 50) high, roundly subtrapeziform, caudal $1+1$ setae strongly separated, borne on minute knobs.

Sternites without modifications, very densely setose, cross-impressions shallow; a pair of round, densely setose tubercles between coxae 4 (Fig. 51). Legs (Figs 43-47) very densely setose, probably incrassate, rather long and slender, ca 1.4 times as long as midbody height $\left(\sigma^{7}\right)$; femora 1-7 slightly inflated ventrally, tarsi 1-7 with brushes ventrally, these latter gradually thinning out on following, postgonopodal tarsi; prefemora without dorsal bulges; adenostyles absent.

Gonopods (Figs 52 \& 53) rather simple; femorite rather stout, showing a ventral fold and a shallow mesal groove, but no other distal outgrowths; solenophore stout and short, typically coiled, tip subunciform and bifid; process a short and spiniform, process $\mathbf{b}$ a large axe-shaped lobe.

REMARKS. The genus Kronopolites Attems, 1914 has recently been reviewed and shown to comprise seven accepted species (all keyed) ranging from the Himalaya of Kashmir, India in the west to Taiwan in the east [Golovatch, 2009b]. The new species keys out as K. swinhoei (Pocock, 1895), but differs in being 

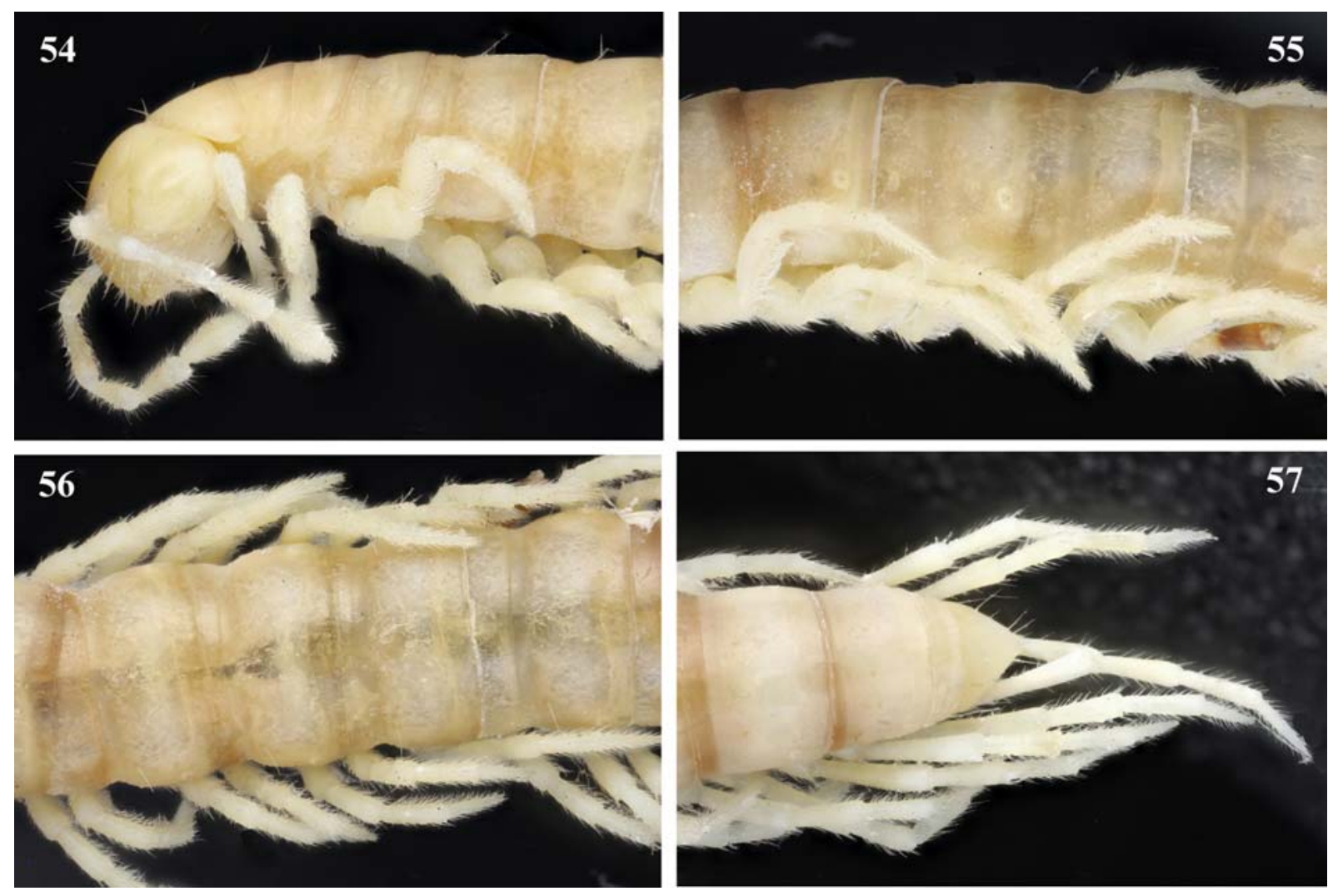

Figs 54-57. Anoplodesmus chinensis sp.n., holotype: 54 - anterior part of body, lateral view; 55-56 - midbody segments, lateral and dorsal views, respectively; 57 - posterior part of body, dorsal view. Photos taken by K. Makarov, not to scale.

Рис. 54-57. Anoplodesmus chinensis sp.n., голотип: 54 - передняя часть тела, сбоку; 55-56 — среднетуловищные сегменты, соответственно сбоку и сверху; 46 - задняя часть тела, сверху. Фото сделаны К. Макаровым, без масштаба.

much smaller (less than $3 \mathrm{~cm}$ long), showing a far less vivid colour pattern, rugose to rugulose metaterga, as well as a distinctive solenophore structure (cp. Figs $1-$ $4 \& 43-53)$

\section{Anoplodesmus chinenis sp.n.}

Figs 54-65.

HOLOTYPE $0^{7}$ (SMF), China, Shaanxi Prov, Taibai Shan Mts, southern slopes, above Houshenzi [6], $107^{\circ} 50^{\prime} \mathrm{E}, 33^{\circ} 51^{\prime} \mathrm{N}$, primary broadleaved forest, 1700-2400 m a.s.1., 09.06.1997, leg. P. Jäger, B. \& J. Martens.

NAME. To emphasize the first Anoplodesmus to be encountered in China.

DIAGNOSIS. Differs from all known congeners by the totally suppressed paraterga 3-19 and evident sternal cones, the conditions observed in many species of the genus, coupled with the rather, but not extremely, long solenomere (sl) and the absence of distogonofemoral outgrowths, as well as in the peculiar shape of the solenophore, including that of the small uncus (h) at the base of the apicomesal lobe (l) (Figs 64 \& 65).

DESCRIPTION. Length ca $20 \mathrm{~mm}$, width of midbody pro- and metazona 1.8 and $2.0 \mathrm{~mm}$, respectively. General coloration in alcohol rather uniformly light yellowish to yellow-brown; anterior third of body and rear halves of some metaterga somewhat darker, yellow-brown (Figs 54-57).

Body subcylindrical, head broadest, slightly broader than subequal collum and most of following segments; body gradually tapering towards telson only starting from segment 17. Clypeolabral region rather sparsely setose, vertex with $1+1$ setae. Antennae rather slender and short, only slightly clavate, extending behind metatergum 2 when stretched dorsally $\left(O^{7}\right)$. Collum with regularly and broadly rounded flaps. Paraterga present only in segment 2, also rounded, anteriorly extended and not fully declined ventrad (Fig. 54). Following paraterga virtually missing, in pore-bearing segments traced due to rather obscure ozopores set at about half of midbody height. Ozopores lateral, rather poorly discernible, mostly lying at about caudal quarter of metatergite's length. Body surface mostly smooth, poorly shining. Axial line and transverse metatergal sulci absent. Tergal setae often abraded, rather long (ca $1 / 3$ of metatergite's length, same as on head), but pattern usually traceable as insertion points arranged in three transverse rows on collum (ca 4+4, 2+2 and 2+2) and in a front transverse row of $3+3$ or $2+2$ setae (Figs 54, 56 \& 58). Stricture dividing pro- and metazona shallow, rather broad, nearly smooth at bottom. Pleu- 


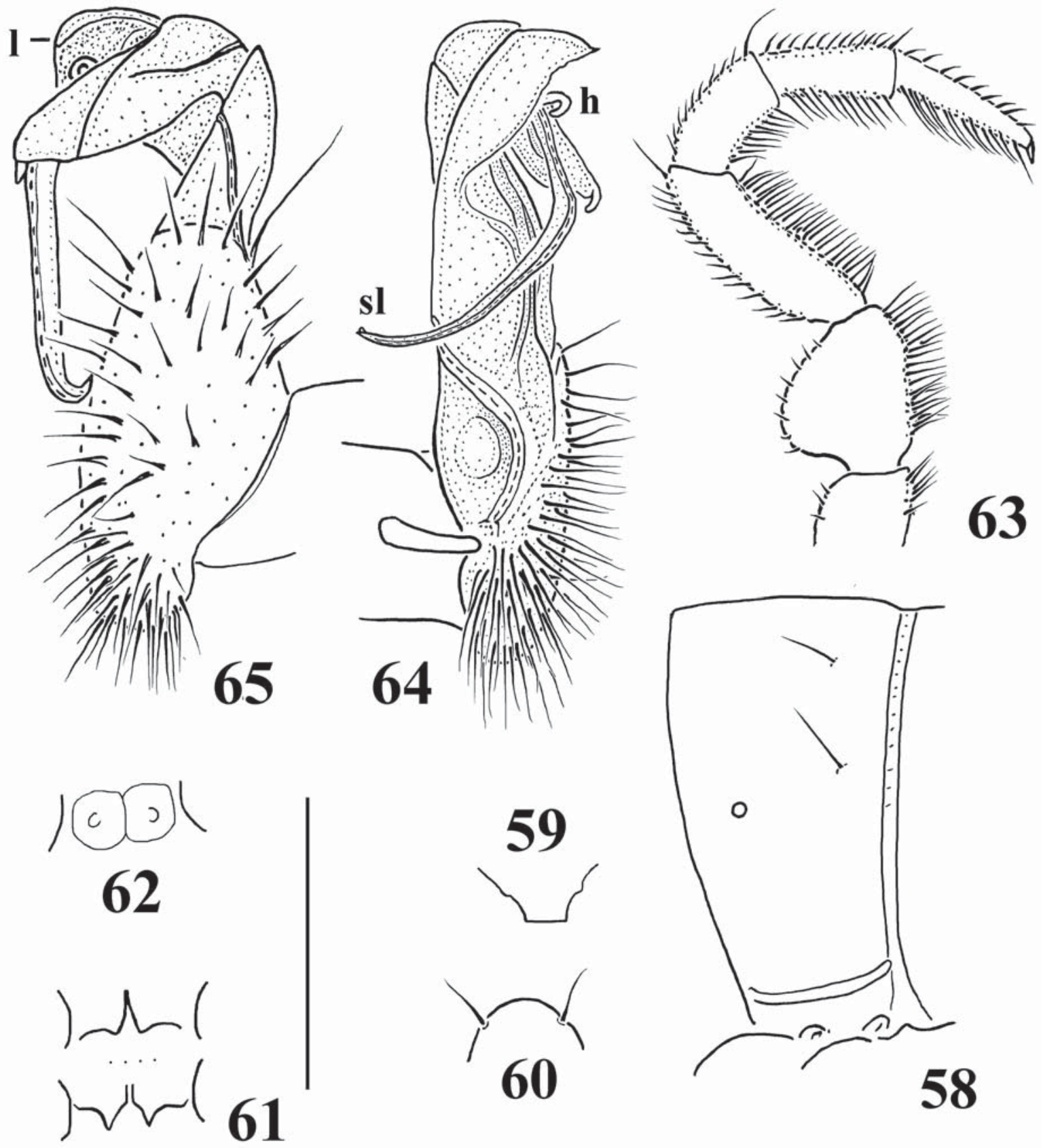

Figs 58-65. Anoplodesmus chinensis sp.n., holotype: 58 - body segment 10, lateral view; 59 - epiproct, dorsal view (tip down); 60 - hypoproct, ventral view; 61 - midbody sternal cones, ventral view; 62 - sternal cones between coxae 4, ventral view; 63 - leg 9 , lateral view; 64-65 - left gonopod, mesal and lateral views, respectively. Scale bars: 1.0 (58-63) and 0.5 mm (64-65).

Рис. 58-65. Anoplodesmus chinensis sp.n., голотип: 58 - туловищный сегмент 10, сбоку; 59 - эпипрокт, вид сверху (вершина снизу); 60 - гипопрокт, вид снизу; 61 - среднетуловищные стернальные бугорки, вид снизу; 62 - стернальные бугорки между тазиками 4, вид снизу; 64-65 - левый гонопод, соответственно изнутри-сбоку. Масштаб 1,0 (58-63) и 0,5 мм (64-65).

rosternal carinae (Figs 54-58) mostly strongly developed, arch-shaped, devoid of a caudal tooth, gradually coming to naught towards segment $18\left(\sigma^{\top}\right)$. Epiproct (Figs 57 \& 59) rather short, flattened dorsoventrally, tip subtruncate, subapical papillae very small. Hypoproct (Fig. 60) high, semi-circular, caudal $1+1$ setae strongly separated.
Sternites behind gonopods with small, but evident cones (Fig. 61), very densely setose, cross-impressions shallow; a pair of low, round, densely setose tubercles between coxae 4 (Fig. 62). Legs (Figs 54-57 \& 63) probably incrassate, clearly growing longer towards telson, ca 1.3-1.4 times as long as midbody height $\left(O^{7}\right)$, very densely setose, ventral brushes throughout 

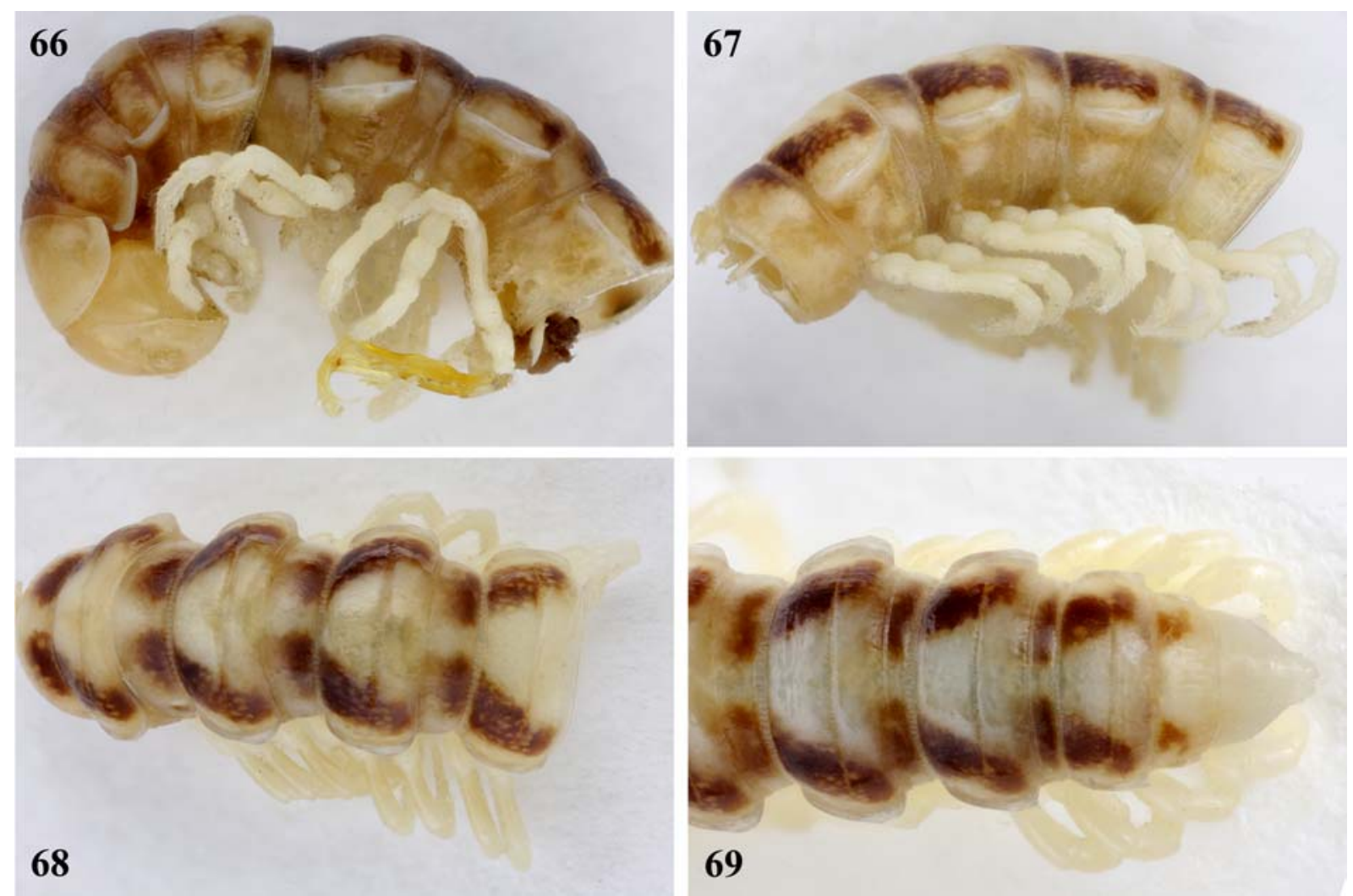

Figs 66-69. Inversispina trispina sp.n., holotype: 66 - anterior part of body, lateral view; 67-68 - midbody segments, lateral and dorsal views, respectively; 69 - posterior part of body, dorsal view. Photos taken by K. Makarov, not to scale.

Рис. 66-69. Inversispina trispina sp.n., голотип: 66 - передняя часть тела, сбоку; 67-68 - среднетуловищные сегменты, соответственно сбоку и сверху; 69 - задняя часть тела, сверху. Фото сделаны К. Макаровым, без масштаба.

except for a few leg-pairs in front of telson; prefemora with dorsal bulges (Fig. 63); adenostyles absent.

Gonopods (Figs 64 \& 65) rather complex; coxite quite long, with a few setae distoventrally; telopodite rather stout, prefemoral (= densely setose) portion about as long as acropodite; femorite devoid of outgrowths, supporting a laterally shifted seminal groove; solenophore elongate, with a distinct, rounded, apicomesal lobe (l) with a small uncus (h) at base; solenomere (sl) long, much longer than solenophore, directed mostly mesad, somewhat coiled.

REMARKS. Anoplodesmus Pocock, 1895 is a large genus encompassing over 30 species or subspecies from southern and northern India and Sri Lanka in the west, through the Himalaya, Myanmar and Sumatra, to mainland Malaysia, mainland Thailand, as well as Vietnam and Taiwan in the east [Chen et al., 2010a; Nguyen, 2010]. Some of the species show rather evident paraterga and particularly simple gonopods, whereas the others have strongly reduced, vestigial to totally suppressed paraterga, often conspicuous sternal cones in both sexes, ventral brushes on some $\sigma^{\gamma}$ tibiae and tarsi, as well as highly complex/elaborate gonopods. Some of the species display intermediate conditions, the reason why both of these species complexes are being considered as representing a single genus. The distribution of both complexes fails to show any meaningful patterns, with simpler or more complex gonopod-bearing congeners occurring more or less randomly across almost any part of the generic range [Chen et al., 2010a].

Anoplodesmus chinenis sp.n. definitely belongs to the group of species with strongly reduced paraterga and quite elaborate gonopods, also representing the northwesternmost congener known to date.

\section{Inversispina trispina sp.n.}

Figs 66-77.

HOLOTYPE O (SMF), China, Sichuan Prov., Mt Emei Shan [5], Wannian Monastery, $103^{\circ} 19^{\prime} \mathrm{E}, 29^{\circ} 32^{\prime} \mathrm{N}$, secondary broadleaved forest, $1050 \mathrm{~m}$ a.s.1., 19-30.03.1999, leg. W. Schawaller.

PARATYPES: 2 우 (SMF), same data, together with holotype.

NAME. To emphasize the presence of three, not two, lateral spines at the base of the solenophore.

DIAGNOSIS. Differs from all hitherto known congeners except I. erectispina Golovatch, 2012, from Sichuan [Golovatch, 2012], by the lateral processes located at the base of a parabasally geniculate solenophore being suberect and spiniform, from I. erectispina by the presence of a peculiar colour pattern and three, 


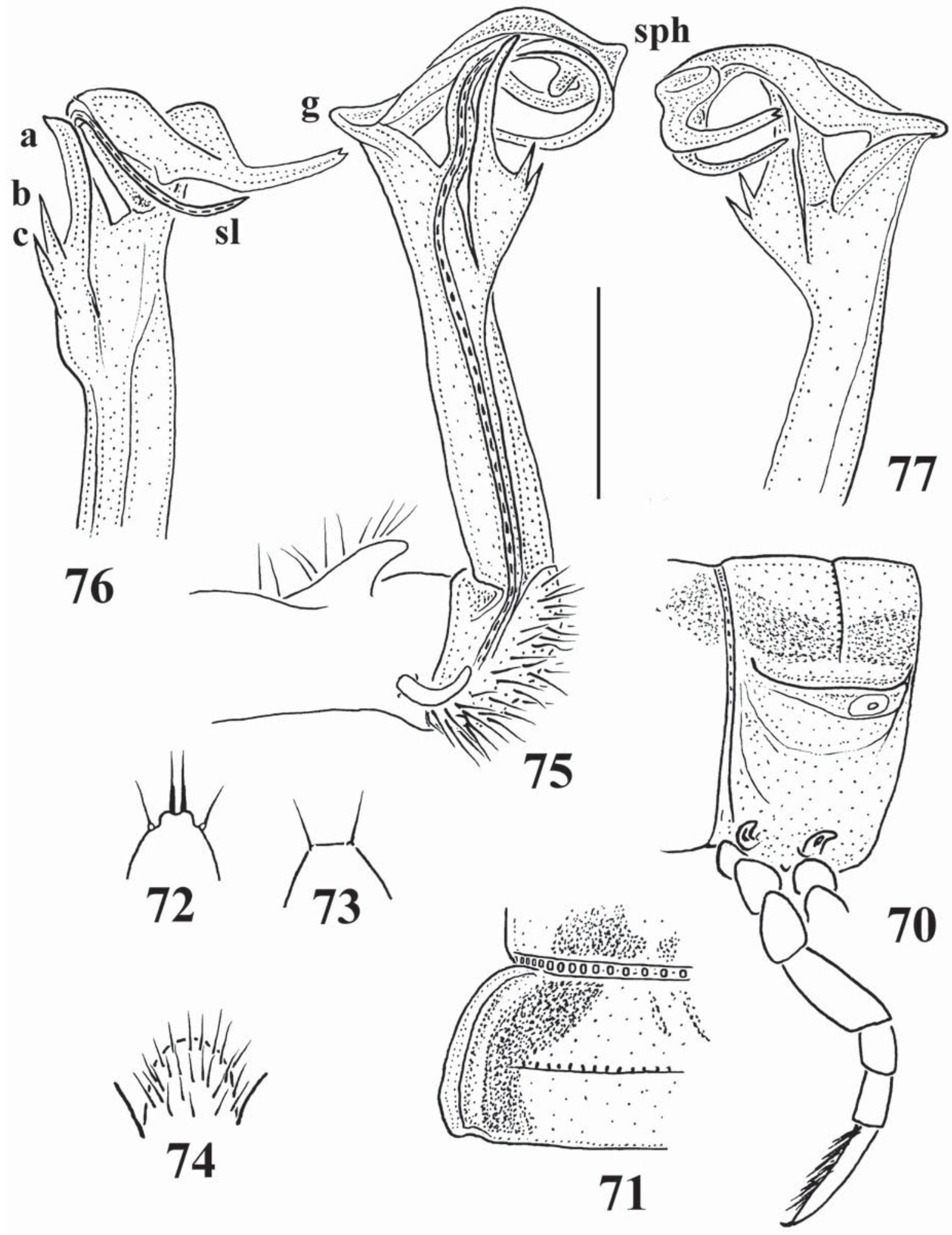

Figs 70-77. Inversispina trispina sp.n., holotype: 70-71 - body segment 10, lateral and dorsal views, respectively; 72 - epiproct, dorsal view; 73 - hypoproct, ventral view; 74 - sternal lobe between coxae 4 , ventrocaudal view; $75-77$ - left gonopod, mesal, ventral and lateral views, respectively. Scale bars: $1.0(70-74)$ and $0.5 \mathrm{~mm}(75-77)$

Рис. 70-77. Inversispina trispina sp.n., голотип: 70-71 - туловищный сегмент 10, соответственно сбоку-сверху; $72-$ эпипрокт, вид сверху; 73 - гипопрокт, вид снизу; 74 - стернальная пластинка между тазиками 4, вид одновременно сзади и снизу; 75-77 - левый гонопод, соответственно изнутри, снизу и сбоку. Масштаб 1,0 (70-74) и 0,5 мм (75-77). 
not two, such processes (a, b and $\mathbf{c}$ ), of which $\mathbf{a}$ is considerably longer than both $\mathbf{b}$ and $\mathbf{c}$ (Figs 75-77).

DESCRIPTION. Length ca $19\left(\sigma^{7}\right)$ or $20-21 \mathrm{~mm}$ $(+)$, width of midbody pro- and metazona 1.7 and 2.0 $\left(\sigma^{7}\right)$, or 1.9 and $2.2 \mathrm{~mm}(+)$, respectively. General coloration in alcohol rather uniformly light whitish to yellowish (Figs 66-72) with a vivid pattern; collum mostly light brown, rather broadly flavous along front margin and on sides, also with a clear, light, median, triangular spot at caudal edge; all following segments, excluding telson, with a paramedian pair of only slightly separated, marbled brown spots in rear third of prozona, these marbled brown spots extending behind a light stricture into two similarly broad, semi-lunar ribbons along bases of paraterga; axial line missing. Antennomeres 6 and 7 infuscate, brown.

In width, head $<$ collum $<$ segment $3<$ segments 2 and $4<5-16$; after segment 16 , body gradually tapering towards telson. Clypeolabral region densely setose, vertigial region with $1+1$ setae. Antennae slender and rather short, extending behind metatergum $2\left(O^{7}\right)$ or collum ( + ) when stretched dorsally. Paraterga modest (Figs 66-71), a little more strongly developed in $\sigma^{7}$ compared to 9 , set rather low, mostly lying at about $1 / 3$ of midbody height; caudal corner mostly well rounded and lying within tergal contour, only in segments 17 and 18 narrowly rounded and subrectangular, in segment 17 a little extending behind tergal margin. Paraterga of collum and segment 2 clearly declined more ventrad than lateral, in collum broadly and regularly rounded anterolaterally, but angular, more narrowly rounded caudally; in segment 2 similar, but slightly extending behind rear tergal margin; following paraterga subhorizontal, thin keels slightly thicker in caudal part in pore-bearing segments compared to poreless ones; lateral calluses narrow, each delimited by a deep sulcus dorsally and by a somewhat weaker sulcus in rear $2 / 3^{\text {rds }}$ ventrally; calluses always broadly rounded anteriorly, devoid of denticles at lateral margin. Ozopores lateral, nearly invisible from above, placed inside an ovoid groove at about caudal quarter of metatergite's length, only in segments 17-19 shifted increasingly close to caudal end. Body surface shining, mostly smooth, metaterga very faintly rugulose at most; sides below paraterga finely microgranulate and often faintly rugulose. Tergal setae short, ca $1 / 5$ as long as metaterga, visible as $4+4$ a little longer setae in a front row on collum and as $2+2$ slightly shorter setae in a front row on metaterga 2 and 3, thereafter fully obliterated, setation pattern untraceable. Transverse metatergal sulcus evident, complete, thin, slightly not reaching bases of paraterga in segments 5-18, poorly striate at bottom. Stricture dividing pro- and metazona clearly beaded or striate down to below paraterga (Figs 66-71). Pleurosternal carinae like arcuate ribs evident only in segments 2 and 3, visible as an increasingly obliterated caudal tooth traceable until segment $8\left(\sigma^{7}\right)$ or $4(+)$, thereafter missing. Epiproct (Figs 69 \& 72) slightly concave at tip, subapical papillae unusually prominent.
Hypoproct (Fig. 73) subtrapeziform, caudal 1+1 setae strongly separated.

Sternites without modifications, rather sparsely setose, cross-impressions shallow; a high, linguiform, densely setose lamina between $\sigma^{7}$ coxae 4 (Fig. 74). Legs (Figs 66-70) rather densely setose, slightly incrassate in $\sigma^{7}$, slenderer in + , long, ca 1.3-1.4 $\left(\sigma^{7}\right)$ or 0.9-1.0 times ( $(+)$ as long as midbody height; $\sigma^{7}$ prefemora without evident lateral bulges; ventral brushes present only in $\sigma^{7}$ tarsi 1-7; adenostyles absent.

Gonopods (Figs $66 \&$ 75-77) rather complex; coxite long, subcylindrical, with a group of setae and a rather prominent horn distoventrally; femorite long and slender, not enlarged distad, with one considerably longer and two shorter spines (a, b and c) laterally somewhat basally of a long, flagelliform solenomere (sl); solenophore (sph) slender, simple, evidently coiled, distinctly separated from, and about as long as, solenomere, with a marked dorsal geniculation $(\mathbf{g})$ near base.

REMARKS. Inversispina Zhang, in Zhang, Wang \& Zhang, 1997, has hitherto been known to comprise only three species: I. tortiapicalis Zhang, in Zhang, Wang \& Zhang, 1997 (the type-species), from a southtemperate woodland at $1100 \mathrm{~m}$ elevation in the Wuling Mountains, southern Hubei Province, central China (29.8ÚN, 110.0ÚE), I. taiwanensis Chen, Golovatch \& Chang, 2011, from low- to midmontane woodlands in the northern and northeastern parts of Taiwan, and $I$. erectispina Golovatch, 2012, from near Mianning, Sichuan Province, southern China [Zhang et al., 1997; Chen et al., 2011; Golovatch, 2012]. The new species fails to alter the present-day diagnosis of Inversispina [Golovatch, 2012].

\section{Gonobelus martensi sp.n.}

Figs 78-90.

HOLOTYPE $\sigma^{7}$ (SMF), China, Shaanxi Prov., Taibai Shan Mts, S slopes, above Houshenzi [6], $107^{\circ} 50^{\prime} \mathrm{E}, 33^{\circ} 51^{\prime} \mathrm{N}$, primary broadleaved forest, 1700-2600 m a.s.1., 9.06.1997, leg. P. Jäger, B. \& J. Martens.

PARATYPES: $1 \sigma^{7}$ (SMF), $1 \sigma^{7}$ (ZMUM), same data, together with holotype; $1 \sigma^{7}$ (incomplete, lacking segments 18-20) (SMF), same locality, secondary broadleaved forest, $1300-1700 \mathrm{~m}$ a.s.1., 21.06.-03.07.1997, leg. J. Martens \& P. Jäger; 1 o (incomplete, lacking segments 15-20) (SMF), same data, 19.06.1997, leg. J. Martens \& P. Jäger.

NAME. Honours Jochen Martens, Mainz, Germany, my good friend and one of the main collectors.

DIAGNOSIS. Gonobelus sinensis Attems, 1936, the type, and only other known, species of the genus, differs from $G$. martensi sp.n. by several somatic and gonopod characters such as a much larger body (width $2.6 \mathrm{~mm}$ ), a bare vertex, a rougher texture of the tegument (surface of metazonites roughly rugose, sides clearly granulate), far more narrow, but deep metatergal sulci, less strongly ribbed strictures between pro- and metazona, mostly rounded and non-spiniform caudal corners of paraterga (Figs 91 \& 92), coniferous sterna, 

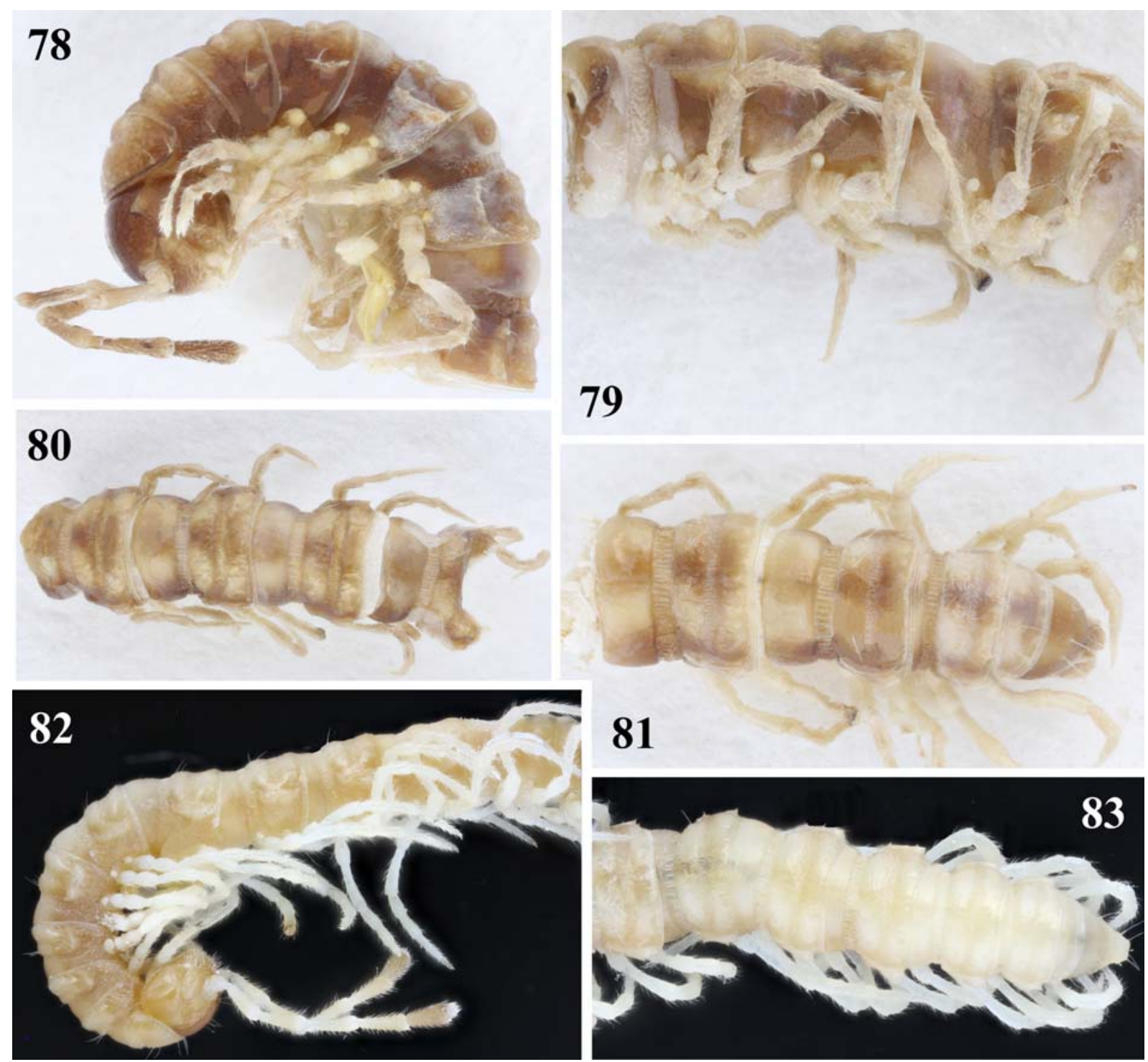

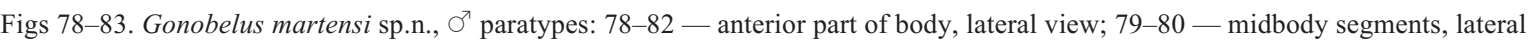
and dorsal views, respectively; 81-83 - posterior part of body, dorsal view. Photos taken by K. Makarov, not to scale.

Рис. 78-83. Gonobelus martensi sp.n., паратипы $0^{7}:$ 78-82 - передняя часть тела, сбоку; 79-80 - среднетуловищные сегменты, соответственно сбоку и сверху; 81-83 - задняя часть тела, сверху. Фото сделаны К. Макаровым, без масштаба.

a much shorter spine at the base of the solenophore, and the solenomere starting basal to the solenophore and branching at about midway. This latter feature appears to also vary between species, but the presence of adenotyles on $\sigma^{7}$ prefemora 1, of a strongly coiled solenophore bearing a spine at its base, and of a flagelliform, similarly coiled solenomere starting somewhat basal to the solenophore base seem to be characteristic of the genus (Fig. 93) [cp. Golovatch, 2012].

DESCRIPTION. Length ca 11-12 mm, width of midbody pro- and metazona $0.8-0.9$ and $1.0-1.1 \mathrm{~mm}$, respectively. Holotype ca $12 \mathrm{~mm}$ long, 0.9 and $1.1 \mathrm{~mm}$ wide on pro- and metazona, respectively. General coloration in alcohol rather uniformly light yellowish brown to brown (Figs 78-83), more intense in anterior body part, head especially strongly infuscate dorsally, body paler towards telson, devoid of a pattern; antennae increasingly infuscate distad.

In width, segments 2 and $3<$ head $=$ collum $=$ segment $4<$ segments $5-16$; after segment 16 , body gradually tapering towards telson. Clypeolabral region densely, vertigial region sparsely, setose. Antennae slender, long and barely clavate, extending behind metatergum 3 when stretched dorsally; antennomeres 2-5 subequal in length, $6^{\text {th }}$ only slightly shorter. Paraterga modest (Figs 78-85), set rather low, mostly lying at about $1 / 3$ of midbody height; paraterga of collum broadly and regularly rounded; caudal corner of paraterga 2 narrowly rounded, angulate and only faintly extending behind tergal margin; thereafter caudal corner of paraterga mostly dentiform, but always lying within tergal margin. Postcollum paraterga subhorizontal, thin keels 

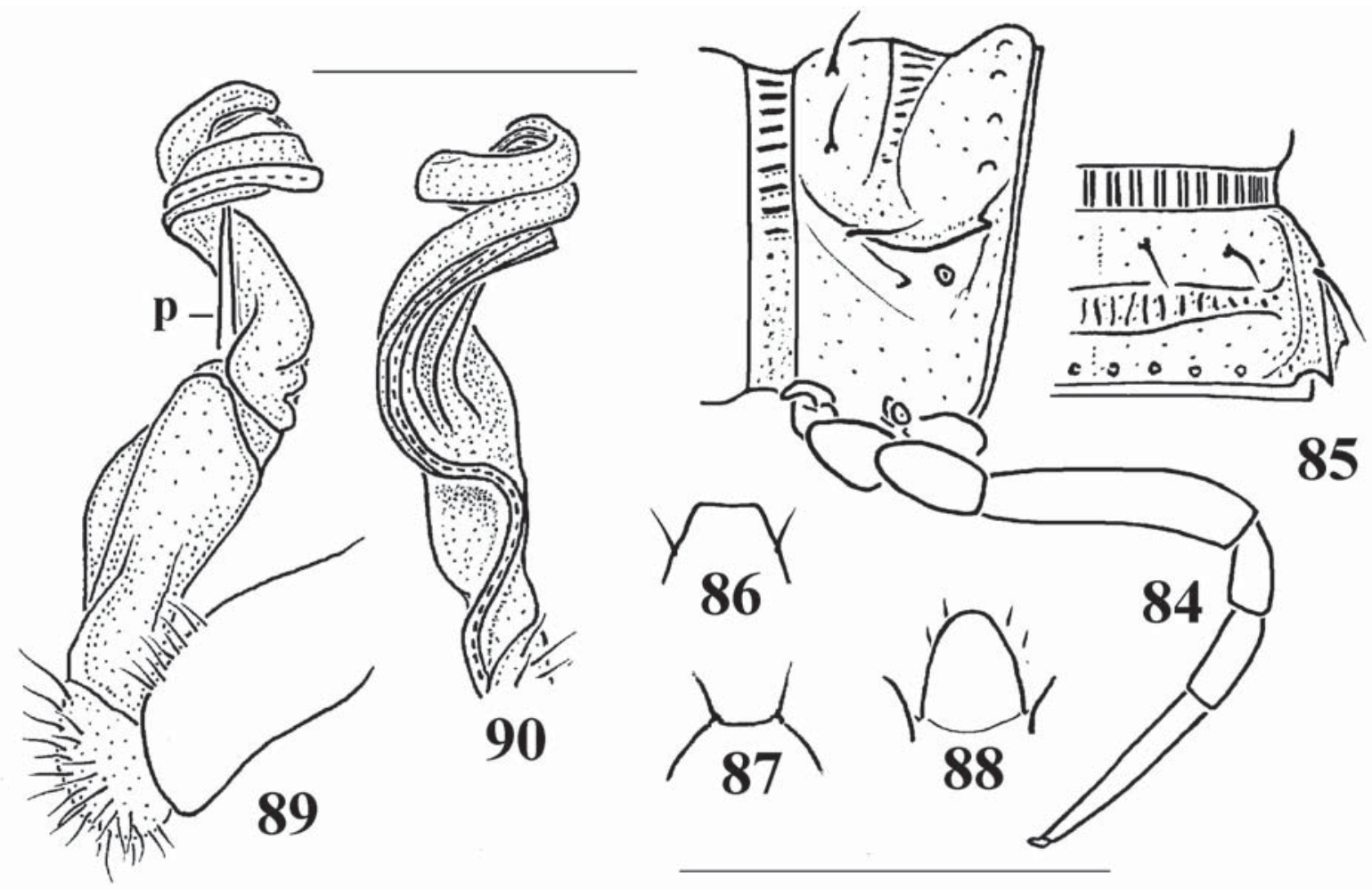

Figs 84-90. Gonobelus martensi sp.n., O7 paratype: 84-85 — body segment 10, lateral and dorsal views, respectively; 86 - epiproct, dorsal view; 87 - hypoproct, ventral view; 88 - sternal lobe between coxae 4, caudoventral view; 89-90 - left gonopod, lateral and mesal views, respectively. Scale bars: $1.0(84-88)$ and $0.5 \mathrm{~mm}(89-90)$.

Рис. 84-90. Gonobelus martensi sp.n., паратип О7: 84-85 - туловищный сегмент 10, соответственно сбоку и сверху; $86-$ эпипрокт, вид сверху; 87 - гипопрокт, вид снизу; 88 - стернальная пластинка между тазиками 4 , вид одновременно сзади и снизу; 89-90 - левый гонопод, соответственно сбоку и изнутри. Масштаб 1,0 (84-88) и 0,5 мм (89-90).

slightly thicker in caudal part in pore-bearing segments compared to poreless ones; lateral calluses narrow, each delimited by a deep sulcus only dorsally; calluses always broadly rounded to nearly straight and slightly skewed anteriorly, with two evident setiferous denticles at lateral margin in poreless segments, with only one such denticle at about anterior third in pore-bearing segments. Ozopores lateral, invisible from above, placed at about caudal quarter to third of metatergite's length, only in segments 17-19 shifted increasingly close to caudal margin. Body surface moderately shining, mostly smooth, metaterga very faintly rugulose at most; sides below paraterga very finely microgranulate. Tergal setae rather long, ca $1 / 3-1 / 4$ as long as metaterga, arranged as $4+4,2+2$ and $2+2$ setae in three transverse rows on minute knobs on collum, and as $2+2$ setae in a front row on following metaterga; another, hind row of $4+4$ obviously fully obliterated setae visible only as insertion points (Figs $84 \& 85$ ). Transverse metatergal sulcus very broad and deep, distinctly dividing metaterga into two halves, incomplete and slightly shallower in segments 4 and 18 , complete, reaching bases of paraterga and clearly striate or ribbed at bottom in segments 5-17. Stricture dividing pro- and metazona broad, very strongly ribbed down to level of paraterga (Figs 78-85). Pleurosternal carinae like round- ed lobules only in segment 2, thereafter missing. Epiproct (Figs 81, 83 \& 86) subtruncate at tip, subapical papillae vestigial. Hypoproct (Fig. 87) subtrapeziform, caudal $1+1$ setae on minute knobs, strongly separated.

Sternites without modifications, rather densely setose, longitudinal impressions considerably shallower than transverse ones; a high, linguiform, densely setose lamina between coxae 4 (Fig. 88). Legs (Figs 78-84) very long, ca 1.9-2.0 times as long as midbody height; $\sigma^{7}$ prefemora without evident lateral bulges; ventral brushes present only in tarsi 1-3(4); small adenostyles present in prefemora 1 (as in Fig. 18).

Gonopods (Figs 89 \& 90) rather complex; coxite long, subcylindrical, setose distoventrally; femorite rather long and slender, not twisted, supporting seminal groove only on its mesal side, about as long as acropodite, with a distinct lateral sulcus demarcating a clearly coiled solenophore, the latter with a long mesal spine (p) at base. A long, flagelliform solenomere devoid of any side branches, about as long as solenophore, starting somewhat basal to solenophore.

REMARKS. Gonobelus Attems, 1936 has hitherto remained monobasic [Attems, 1936, 1937]. Described from Yunnan Province, China, G. sinensis (Figs 9193 ) is similar to, yet quite distinct from, G. martensi 

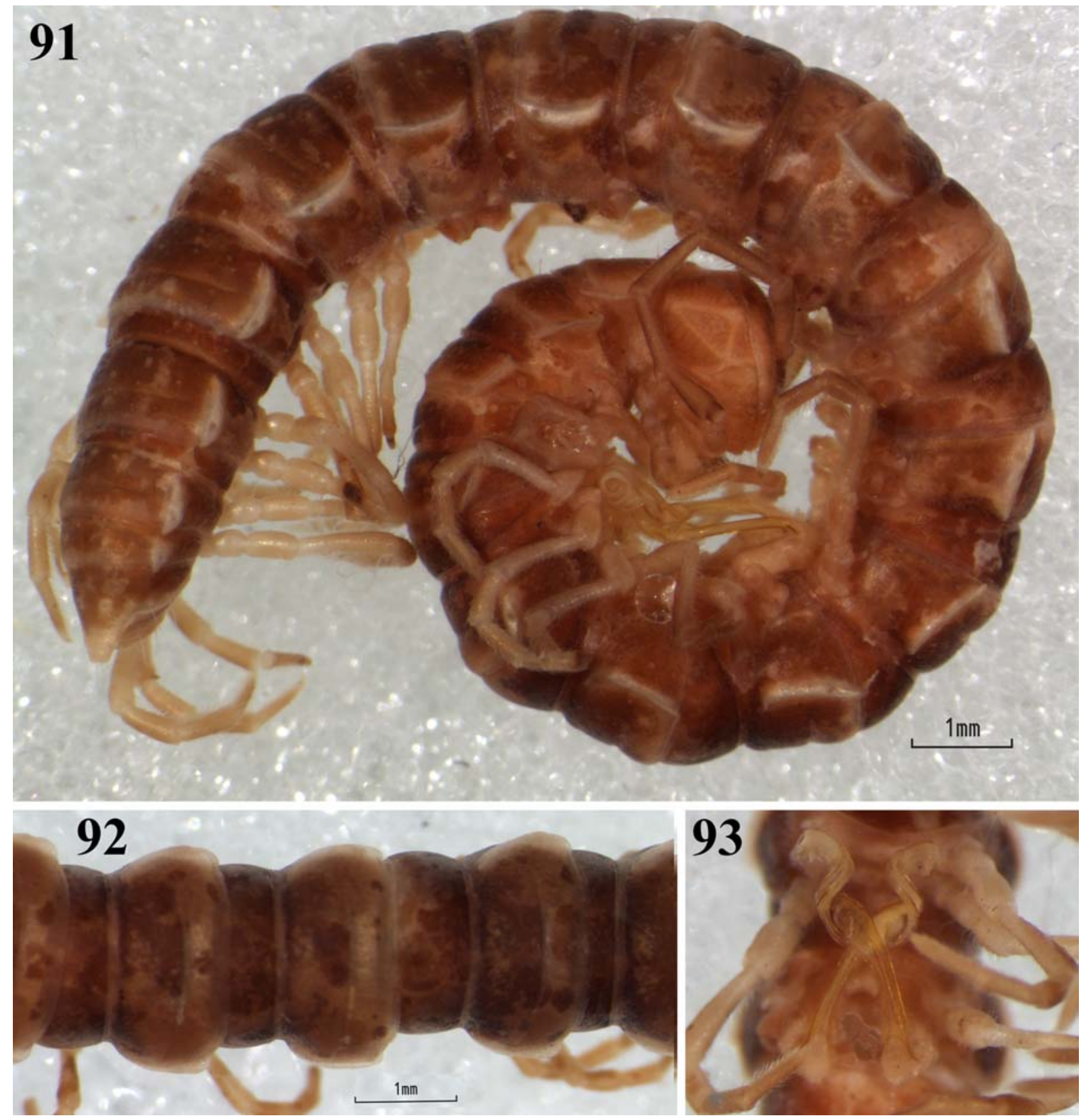

Figs 91-93. Gonobelus sinensis Attems, 1936, $0^{7}$ syntypes: 91 — habitus, lateral view; 92 - midbody segments, dorsal view; 93 gonopods in situ, ventral view. Photos arranged and taken by E. Schiller and V. Stagl (both NHMW), Fig. 93 taken not to scale.

Рис. 91-93. Gonobelus sinensis Attems, 1936, синтипы О’: 91 - габитус, сбоку; 92 - среднетуловищные сегменты, сверху; 93 - гоноподы на месте, снизу. Фото организованы и сделаны Э. Шиллером и В. Штагль (оба из NHMW), рис. 93 без масштаба.

sp.n., based both on peripheral and gonopod characters (see Diagnosis).

The type series housed in NHMW actually contains two $\sigma^{7} \sigma^{7}$, not a $\sigma^{7}$ and a $q$ as stated in the original description [Attems, 1936].

\section{Sellanucheza jaegeri sp.n.}

Figs 94-103.

HOLOTYPE $0^{7}$ (SMF), China, Shaanxi Prov., Taibai Shan Mts, southern slopes, above Houshenzi [6], $107^{\circ} 50^{\prime} \mathrm{E}, 33^{\circ} 51^{\prime} \mathrm{N}$, secondary broadleaved forest, $1300-1700 \mathrm{~m}$ a.s.1., 19.06 .1997 , leg. J. Martens \&. P. Jäger.

PARATYPES: 1 juv. (19 segments) (SMF), same data, together with holotype; $10^{j}$ (incomplete, segments 11-13 missing), $10^{7}$ (fragment of three midbody segments and a gonopod), 1 , 1 ㅇ (incomplete, last two segments missing), 3 juv. (fragmented, two incomplete, all different instars) (SMF), same data, 08.06.1997, leg. P. Jäger, B. \& J. Martens; 1 क (SMF), same data, 07.07.1997, leg. P. Jäger \& J. Martens.

NAME. Honours Peter Jäger (SMF), my good friend and one of the main collectors.

DIAGNOSIS. Differs from all three currently known species of the genus chiefly by solenophore structure, 

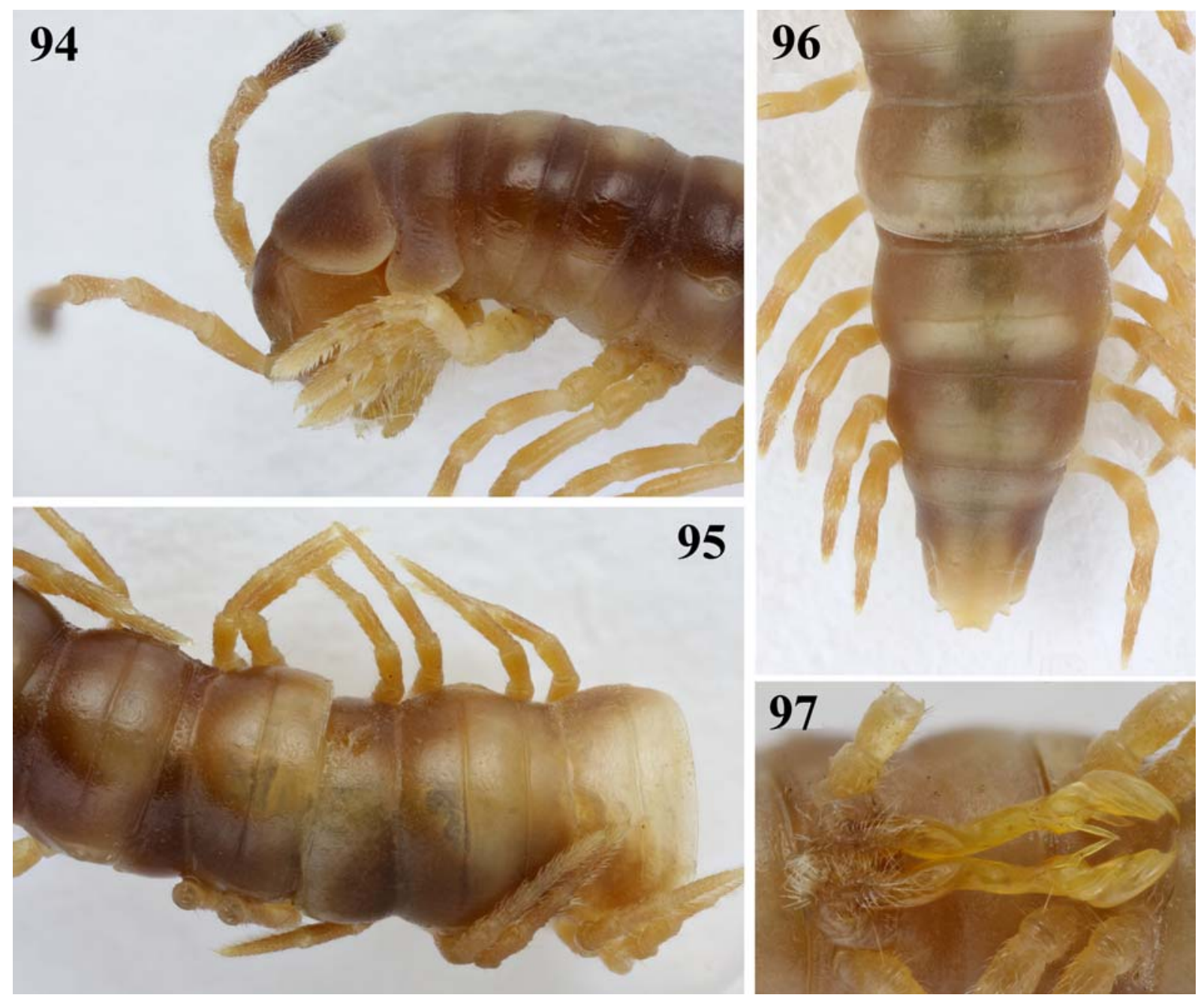

Figs 94-97. Sellanucheza jaegeri sp.n., O OT $^{\top}$ paratype: 94 - anterior part of body, lateral view; 95 - midbody segments, dorsal view; 96 - posterior part of body, dorsal view; 97 - gonopods in situ, ventral view. Photos taken by K. Makarov, not to scale.

Рис. 94-97. Sellanucheza jaegeri sp.n., паратип О’: 94 - передняя часть тела, сбоку; 95 - среднетуловищные сегменты, сверху; 96 - задняя часть тела, сверху; 97 - гоноподы на месте, снизу. Фото сделаны К. Макаровым, без масштаба.

this being short, broad, less strongly coiled, deeply bifid, with both parabasal processes subunciform (see also Key below).

DESCRIPTION. Length of adults ca $30\left(\sigma^{7}\right)$ or 33 $\mathrm{mm}(+)$, width of midbody pro- and metazona 2.4-2.8 and 2.7-3.0 $\mathrm{mm}\left(\mathrm{O}^{7}\right)$, or 3.0-3.1 and 3.2-3.4 $\mathrm{mm}(+)$, respectively. General coloration in alcohol rather uniformly light (Figs 94-97) to dark brown, but collum and all following segments, including telson, with a vague (lighter specimens) to contrasting light greyyellowish or grey (darker specimens), broad (ca 1/3 of metazonite's width), axial stripe, either complete or interrupted into a chain of spots covering most of metaterga and telson except for their anteriormost parts; antennae increasingly infuscate distad, antennomere 7, sometimes both $6^{\text {th }}$ and $7^{\text {th }}$, dark brown.

In width, collum $=$ segments $5-16>$ head $=$ segment $4>$ segments 2 and 3; after segment 16, body gradually tapering towards telson. Clypeolabral region densely setose, vertigial region with $1+1$ setae. Antennae slender and rather long, extending behind metatergum $3\left(\sigma^{7}\right)$ or 2 () when stretched dorsally. Paraterga very poorly developed (Figs 94-96 \& 98), set low, mostly lying at about half of midbody height; caudal corner always rounded and lying within tergal contour. Paraterga mostly slightly declined, collum broadly and regularly rounded laterally; paraterga 2 broadly rounded both frontally and caudally, declined more ventrad than laterad; paraterga thin keels slightly thicker in caudal part in pore-bearing segments compared to poreless ones; each callus delimited by a deep sulcus dorsally, pore-bearing ones also by a somewhat weaker sulcus in rear $2 / 3^{\text {rds }}$ ventrally; calluses always broadly rounded anteriorly, devoid of denticles at lateral margin. Ozopores lateral, placed inside an ovoid groove, lying at about caudal quarter of metatergite's length, only in segments 17-19 shifted increasingly close to caudal margin. Body surface shining, mostly smooth, only rear halves of metaterga above paraterga rugulose; sides 

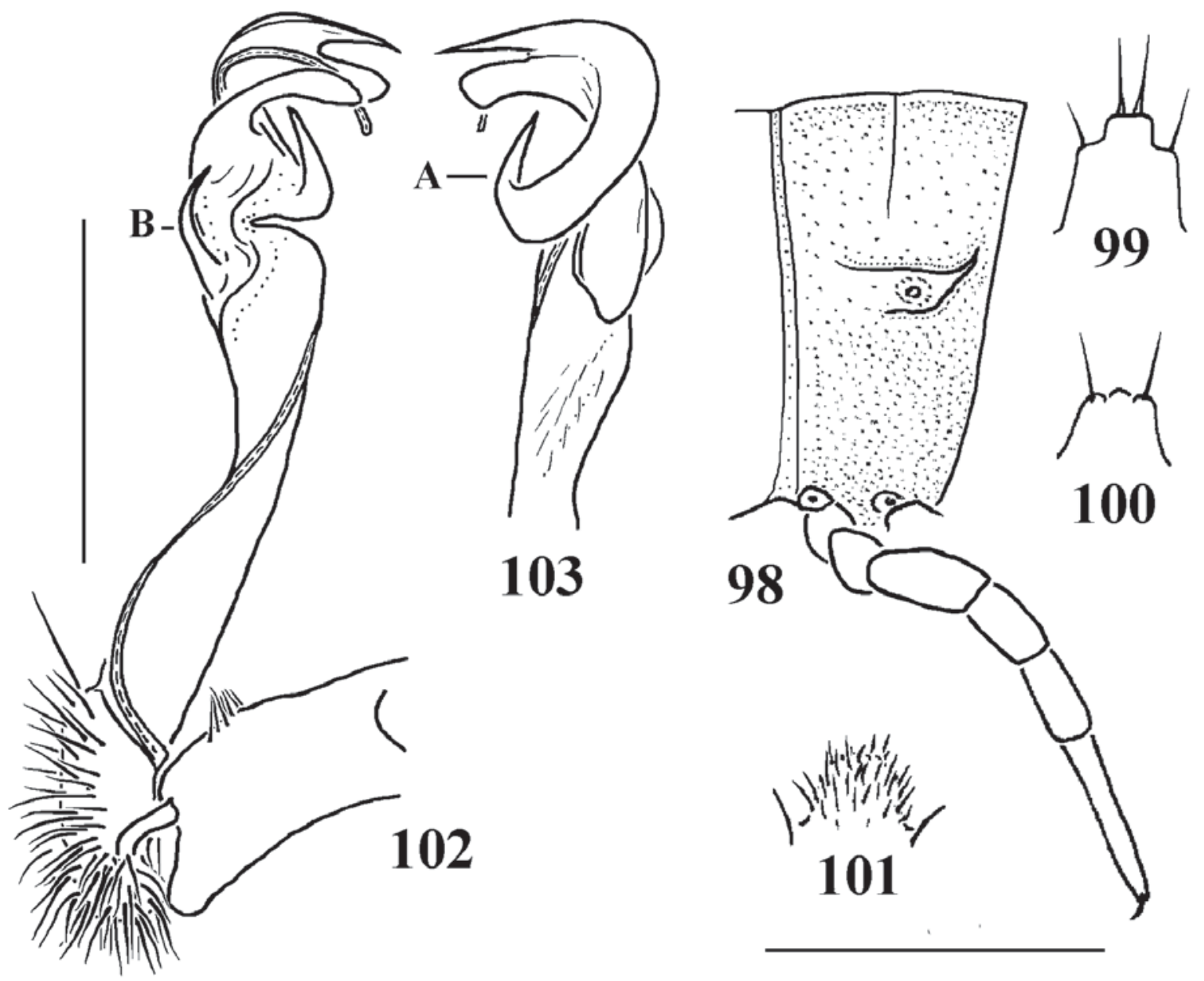

Figs 98-103. Sellanucheza jaegeri sp.n., o' paratype: 98 — body segment 10, lateral view; 99 — epiproct, dorsal view; 100 hypoproct, ventral view; 101 — sternal lobe between coxae 4, caudoventral view; 102-103 — right gonopod, mesal and lateral views, respectively. Scale bars: $1.0(98-101)$ and $0.5 \mathrm{~mm}(102-103)$.

Рис. 98-103. Sellanucheza jaegeri sp.n., паратип О7: 98 - туловищный сегмент 10, сбоку; 99 - эпипрокт, вид сверху; 100 гипопрокт, вид снизу; 101 - стернальная пластинка между тазиками 4, вид одновременно сзади и снизу; $102-103$ - правый гонопод, соответственно изнутри и сбоку. Масштаб 1,0 (98-101) и 0,5 мм (102-103).

below paraterga finely microgranulate. Axial line usually or sometimes traceable on postcollum metaterga. Transverse metatergal sulcus evident, complete, thin, slightly not reaching bases of paraterga in segments 5 18 , nearly smooth at bottom. Tergal setae fully abraded, setation pattern untraceable. Stricture dividing pro- and metazona clearly ribbed or striate down to below paraterga (Fig. 98). Pleurosternal carinae small lobules evident only in segments 2 and 3, thereafter missing. Epiproct (Figs 96 \& 99) slightly concave at tip, subapical papillae unusually prominent. Hypoproct (Fig. 100) subtrapeziform, caudal $1+1$ setae strongly separated.

Sternites without modifications, densely setose, longitudinal impressions considerably shallower than transverse ones; a high, linguiform, densely setose lamina between $\sigma^{7}$ coxae 4 (Fig. 101). Legs (Figs 94$96 \& 98$ ) slender, slightly incrassate in $\sigma^{7}$ compared to \%, ca 1.5-1.6 $\left(\sigma^{7}\right)$ or ca $0.8-0.9$ times $(+)$ as long as midbody height; $O^{7}$ prefemora without evident lateral bulges; ventral brushes absent only from last two pairs of tarsi; adenostyles absent.

Gonopods (Figs 97, 102 \& 103) rather complex; coxite long, subcylindrical, setose distoventrally; femorite rather long and slender, nearly not twisted, supporting seminal groove only on mesal side, suberect, with a distinct lateral sulcus demarcating a moderately coiled and clearly bifid solenophore; apex of femorite and base of solenophore each with a large subunciform process (B ventral and A dorsal, respectively). Solenomere about as long as solenophore.

REMARKS. Sellanucheza Enghoff, Golovatch \& Nguyen Duc, 2004 is a small genus of the tribe Sulciferini which has hitherto been known to contain only three species: the type-species $S$. tenebra (Hoffman, 1961), from Sichuan, China, S. variata (Attems, 1953) and S. grandis (Golovatch, 1984), both latter taxa from northern Vietnam [Enghoff et al., 2004]. The new species fails to alter the generic diagnosis as 
formulated by Hoffman [1961, 1963], being perhaps especially similar to $S$. grandis [see Golovatch, 1984] because of a shorter and less strongly coiled solenophore.

Sellanucheza is transferred herewith from Tonkinosomatini [Jeekel, 1968] to Sulciferini, comb.n., because the Tonkinosomatini seems to be a superfluous taxon while Tonkinosoma Jeekel, 1953, monobasic, from northern Vietnam, is very similar to, if not identical with, Sellanucheza [cp. Jeekel, 1953]. Similarly, Aponedyopus Verhoeff, 1939, another genus originally placed in Tonkinosomatini [Jeekel, 1968], has recently been relocated to the tribe Chamberlinini [Chen et al., 2010b].

The following key can be proposed to separate all four currently known species of Sellanucheza:

1(2) Paraterga 3-19 totally suppressed, at most faint bulges not delimited by a sulcus even dorsally. Solenophore long, about as long as a subunciform gonofemorite, strongly coiled, with two rather large, rounded, subequal lobes at apex. Sichuan, China. .................... S. tenebra

2(1) Paraterga, albeit poorly developed, mostly traceable as bulges delimited by a sulcus at least dorsally. Gonopod femorite more often, but not always, much slenderer and longer, being not so strongly curved. Solenophore usually shorter, often at least one apical branch spiniform.

3(4) Solenophore about as long as gonofemorite, strongly coiled, deeply bifid. Laocai, Vietnam. ..... S. variata

4(3) Solenophore at least 2 times shorter than a slender, suberect gonofemorite, only slightly coiled. .............. 5

5(6) Solenophore tip only faintly bifid, apical lobes small and rounded; solenophore near base with three outgrowths, process $\mathbf{B}$ being a small denticle, placed basal to both a lobe and process A. Ninhbinh, Vietnam.

S. grandis

6(5) Solenophore tip deeply bifid (Figs $102 \& 103$ ), one apical branch spiniform; solenophore near base with two outgrowths, processes $\mathbf{A}$ and $\mathbf{B}$ being long and subunciform. Shaanxi, China. S. jaegeri sp.n.

\section{Antheromorpha rosea sp.n.}

Figs 104-113.

HOLOTYPE $0^{7}$ (SMF), China, Yunnan Prov., Gaoligong Shan Mts, S of Pianma [3], $98^{\circ} 40^{\prime} \mathrm{E}, 25^{\circ} 58^{\prime} \mathrm{N}, 1600-1700 \mathrm{~m}$ a.s.l., 04.06.2011, leg. J. Martens.

NAME. To emphasize the pink colour pattern presumably characteristic of adults in life.

DIAGNOSIS. Differs from all male-based congeners [Jeekel, 1980] by the unusually stout gonopod femorite which is about as long as the acropodite.

DESCRIPTION. Length ca $32 \mathrm{~mm}$, width of midbody pro- and metazona 2.8 and $4.2 \mathrm{~mm}$, respectively. General coloration in alcohol dark brown to blackish brown (Figs 104-107), with a vivid live pattern of apparently intense pink markings retained only in posterior body portion, but in alcohol mostly faded to light yellow; on collum, such markings covering a broad and a narrow band along front and caudal margins, respectively, as well as both paraterga and a median triangu- lar spot at caudal edge (Figs 104-107); following paraterga (both dorsally and ventrally) and caudal $2 / 3$ of metaterga, as well as of epiproct likewise fully flavous, whereas proterga in front of stricture, bases of paraterga, transverse metatergal sulci and an axial line sometimes poorly traceable on metaterga rather light marbled brown, all of them strongly contrasting against a dark brown to blackish background coloration, including head, sides, antennae and legs.

In width, head $<$ collum $<$ segments 3 and $4<$ segment $2<5-16$; after segment 16 , body gradually tapering towards telson. Clypeolabral region densely, vertigial region sparsely, setose. Antennae slender, long and only slightly clavate, extending behind metatergum 3 when stretched dorsally; antennomeres 2-6 subequal in length. Paraterga very strongly developed (Figs 104 109), set rather high, mostly lying at about $1 / 3$ of midbody height; paraterga of collum broadly and regularly rounded; caudal corner of paraterga 2 narrowly rounded, clearly extending behind tergal margin at ca $60^{\circ}$; thereafter caudal corner of paraterga increasingly acutangular, from narrowly rounded to nearly pointed, always extending behind tergal margin, especially strongly so in segments 17-19. Paraterga of collum and segment 2 clearly declivous, most of following ones directed dorsolaterad, in $19^{\text {th }}$ laterad, thick keels slightly thicker in caudal part in pore-bearing segments compared to poreless ones; lateral calluses broad, each delimited by a deep sulcus both dorsally and ventrally; calluses always broadly rounded anteriorly, with a minute denticle at lateral margin at fore quarter in segment 2, thereafter devoid of indentations. Ozopores lateral, traceable from above only due to a sinuous outline of callus, placed at about caudal quarter of metatergite's length, only in segments 17-19 shifted increasingly close to caudal margin. Body surface shining, mostly smooth, metaterga very faintly rugulose at most; sides below paraterga finely rugulose and microgranulate. Tergal setae short, ca $1 / 5$ as long as metaterga, arranged in a front row of $1+1$ or $2+2$ setae retained only in segments 2 and 3, elsewhere fully obliterated; setation pattern untraceable. Transverse metatergal sulcus thin, but rather deep, faintly arcuate forward in the middle, incomplete and not reaching bases of paraterga in segments 4 and 18, complete in segments 5-17, slightly rugose at bottom (Figs 104109). Stricture dividing pro- and metazona rather narrow, deep, finely ribbed to striate down to below paraterga (Figs 108 \& 109). Pleurosternal carinae like evident, sharp, caudal teeth increasingly strongly obliterated towards segment 13 (Figs $104 \& 108$ ), vestigial in segment 14, thereafter missing. Epiproct (Figs 107 \& 110) deeply emarginate at tip, subapical papillae nearly wanting. Hypoproct (Fig. 111) semi-circular, caudal $1+1$ setae on small knobs, strongly separated.

Sternites without modifications, moderately setose, cross-impressions shallow; no lamina between coxae 4 , just a few setae being located there in its stead. Legs (Figs 104-108) very long, ca 1.8-2.0 times as long as midbody height; prefemora not incrassate; ventral 


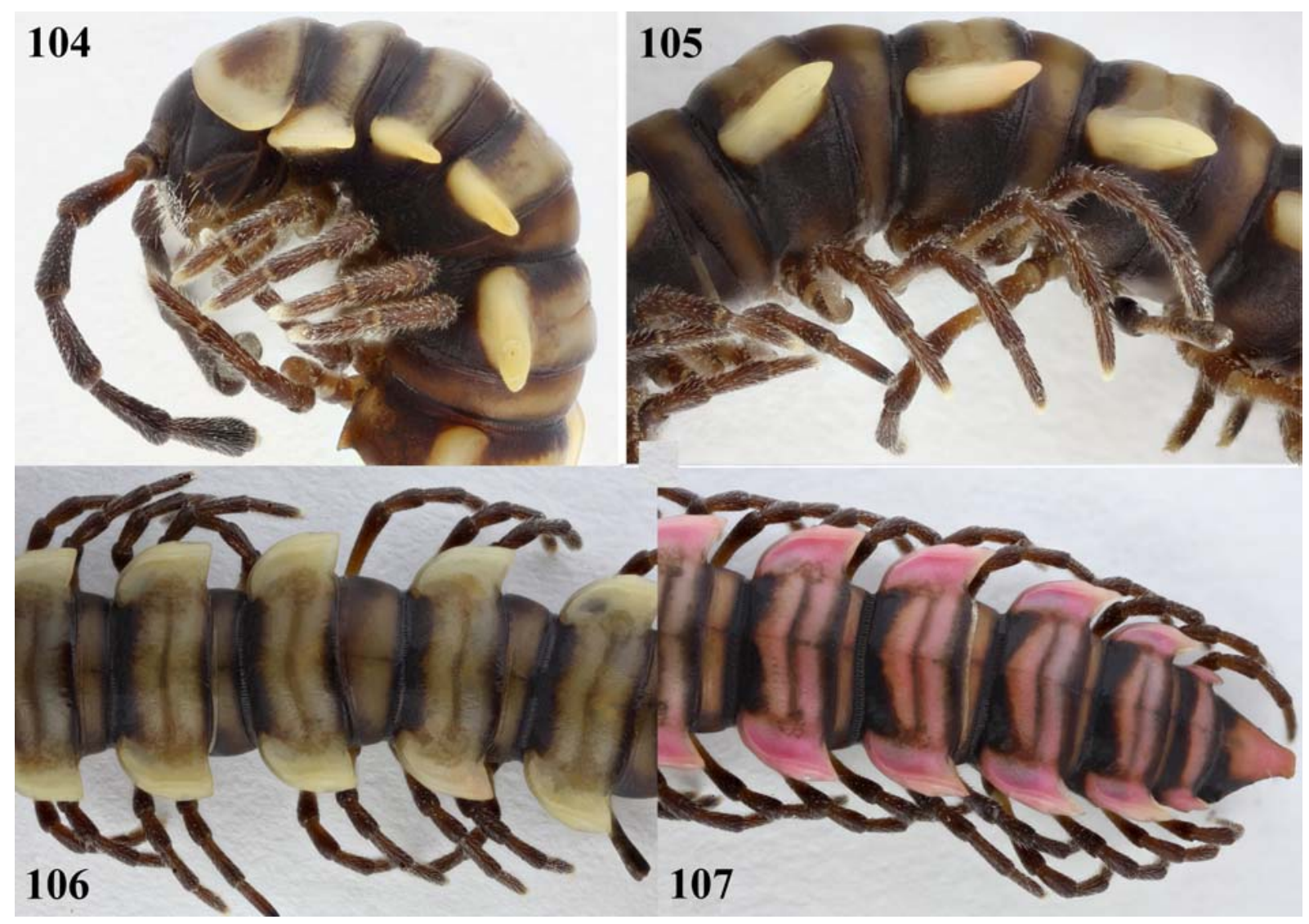

Figs 104-107. Antheromorpha rosea sp.n., holotype: 104 — anterior part of body, lateral view; 105-106 — midbody segments, lateral and dorsal views, respectively; 107 — posterior part of body, dorsal view. Photos taken by K. Makarov, not to scale.

Рис. 104-107. Antheromorpha rosea sp.n., голотип: 104 - передняя часть тела, сбоку; 105-106 — среднетуловищные сегменты, соответственно сбоку и сверху; 107 - задняя часть тела, сверху. Фото сделаны К. Макаровым, без масштаба.

brushes present in all tarsi but two last pairs; adenostyles absent.

Gonopods (Figs 112 \& 113) relatively complex, rather stout; coxite long, subcylindrical, setose distoventrally; telopodite slightly curved ventrad; femorite rather short, about as long as acropodite, not twisted, supporting seminal groove only on its mesal side, with a distinct lateral sulcus demarcating a suberect solenophore (sph), the latter bifurcate near tip, with a long mesal spine (s) and an axe-shaped lateral branch (lb), both supporting the end of a long, flagelliform solenomere (sl).

REMARKS. Antheromorpha Jeekel, 1968 is a large genus of the purely Oriental tribe Orthomorphini which currently harbours 12 species, all quite large-sized, described from Myanmar (9), Thailand (2) and Vietnam (1) [Jeekel, 1980]. A few more, still undescribed congeners have been encountered in Thailand [N. Likhitrakarn, personal communication]. Thus, $A$. rosea sp.n. is the first formal congener to be recorded in China. Based on the large size, very strongly developed paraterga and gonopod structure, in particular, the deeply bifurcate and differentiated tip of the solenophore, this is a rather typical species of Antheromorpha, yet quite distinct due to the relatively stout gonofemorite.

\section{Sinomorpha gen.n.}

Type species: Sinomorpha setosa sp.n., by present designation.

DIAGNOSIS. A genus of Orthomorphini with 20 segments. Body medium-sized $(<30 \mathrm{~mm}$ long and $<$ $4.0 \mathrm{~mm}$ wide). Paraterga well-developed. Adenostyles in $\sigma^{7}$ legs missing. Sternal cones between $\sigma^{\gamma}$ coxae 4 present.

Gonopods (Figs 123 \& 124) quite simple and stout; coxite long, subcylindrical, setose distoventrally; telopodite suberect; femorite stout, not twisted, supporting seminal groove on its mesal side, with a distinct, oblique, lateral sulcus (s) demarcating a postfemoral portion crowned with a broad and stout solenophore (sph), with a quite prominent lamina lateralis and a far more strongly developed lamina medialis, both laminae nearly completely sheathing a long, flagelliform solenomere (sl).

NAME. To emphasize China, the terra typica. 


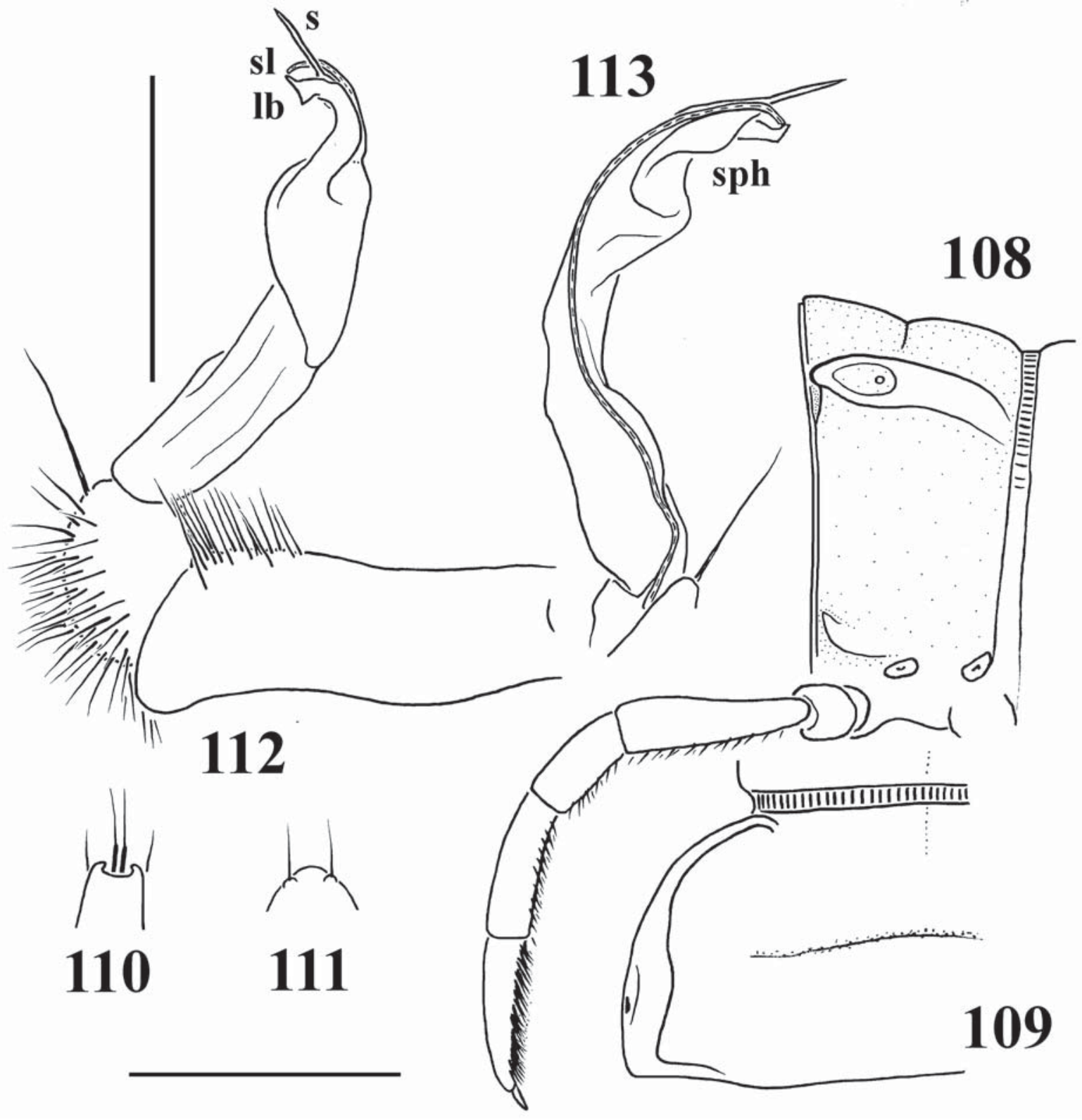

Figs 108-113. Antheromorpha rosea sp.n., holotype: 108-109 — body segment 10, lateral and dorsal views, respectively; 110 epiproct, dorsal view; 111 - hypoproct, ventral view; 112-113 - left gonopod, lateral and mesal views, respectively. Scale bars: 2.0 (108-111) and $1.0 \mathrm{~mm}(112-113)$.

Рис. 108-113. Antheromorpha rosea sp.n., голотип: 108-109 - туловищный сегмент 10, соответственно сбоку и сверху; 110 эпипрокт, вид сверху; 111 - гипопрокт, вид снизу; 112-113 - левый гонопод, соответственно сбоку и изнутри. Масштаб 2,0 (108-111) и 1,0 мм (112-113).

REMARKS. Only a few of all 21 genera currently known to constitute the large tribe Orthomorphini appear to show the gonopods with a clear-cut lateral sulcus demarcating a postfemoral region. In this respect, Sinomorpha gen.n. joins the very large genus Orthomorpha Bollman, 1893 (albeit only some of its species) [Likhitrakarn et al., 2011], as well as further three genera, all rather speciose: Arthrogonopus Jeekel, 1963, Gigantomorpha Jeekel, 1963, both latter taxa fully or mainly from Borneo [Golovatch, 1996], and the Javan Nesorthomorpha Jeekel, 1980 [Golovatch \& Wytwer, 2001].

In the latest key to the genera of Orthomorphini [Golovatch, 1997], because of its quite massive solenophore, but discarding the lateral femoral sulcus, the new genus keys out as Orangutana Golovatch, 1996, monobasic, from Borneo [Golovatch, 1996], but it differs in a much stouter gonofemorite and a unipartite, not bifid, lamina medialis of a twisted solenophore. Sinomorpha gen.n. also resembles both Nepalomorpha 

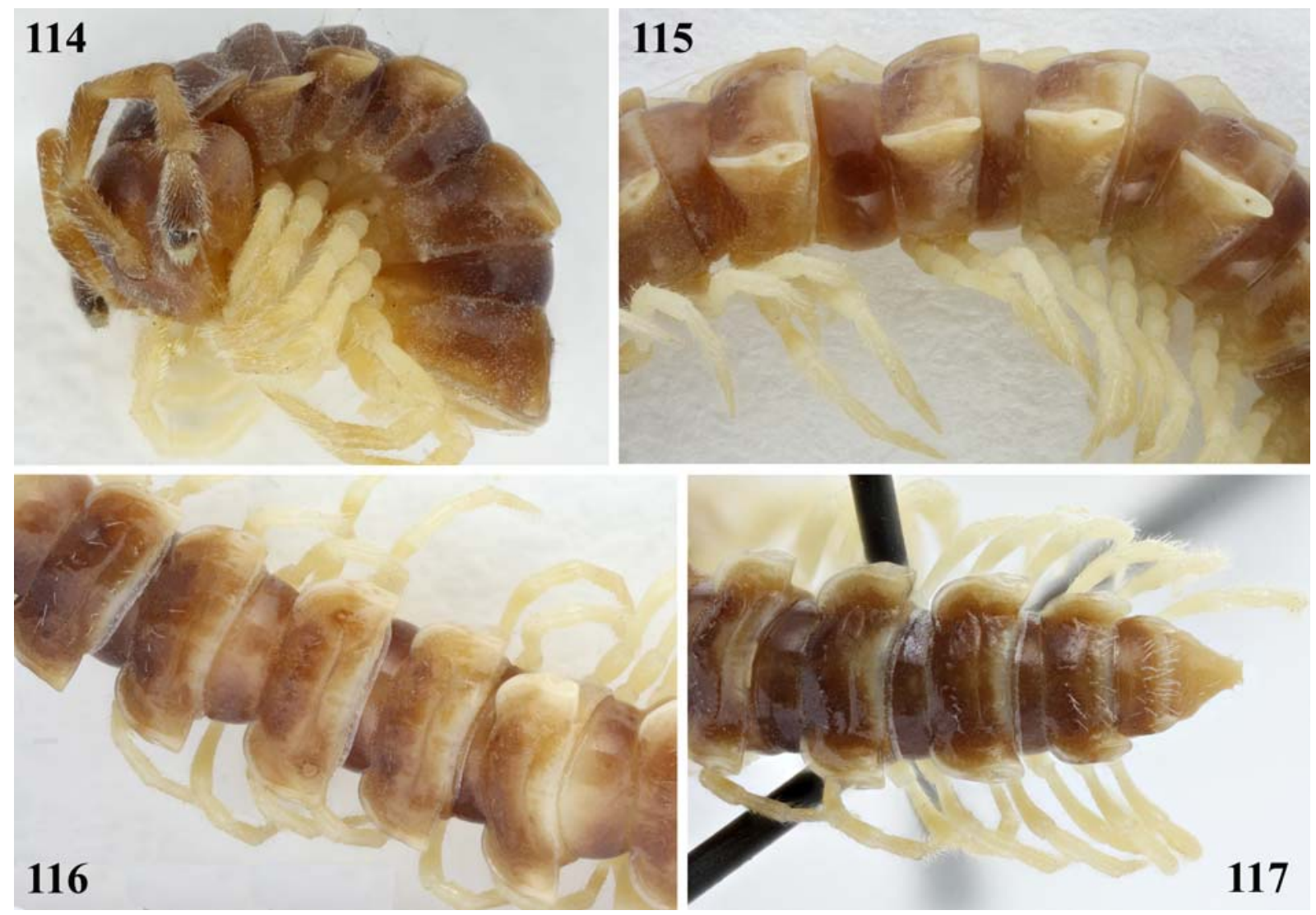

Figs 114-117. Sinomorpha setosa sp.n., o paratype: 114 — anterior part of body, lateral view; 115-116 — midbody segments, lateral and dorsal views, respectively; 117 - posterior part of body, dorsal view. Photos taken by K. Makarov, not to scale.

Рис. 114-117. Sinomorpha setosa sp.n., паратип О’: 114 - передняя часть тела, сбоку; $115-116$ - среднетуловищные сегменты, соответственно сбоку и сверху; 117 - задняя часть тела, сверху. Фото сделаны К. Макаровым, без масштаба.

Golovatch, 1994, a small genus from the Himalaya of Nepal [Golovatch, 1994], and Malayorthomorpha Mršić, 1996, monobasic, from Perak State, Malaysia [Mršić, 1996], in particular, by sharing a broad, distinctly enlarged, albeit clearly bifurcate, lamina medialis. Yet the differences, especially the absence of a lateral gonofemoral sulcus in the latter two genera, seem to be sufficiently strong to warrant the recognition of a separate genus to incorporate the following new species alone.

\section{Sinomorpha setosa sp.n.}

Figs 114-124.

HOLOTYPE $0^{7}$ (SMF), China, Sichuan Prov., Mt Emei Shan [5], Wannian Monastery, $103^{\circ} 19^{\prime} \mathrm{E}, 29^{\circ} 32^{\prime} \mathrm{N}$, secondary broadleaved forest, $1050 \mathrm{~m}$ a.s.1., 19-30.03.1999, leg. W. Schawaller.

PARATYPES: $10^{T}, 3$ 우 (SMF), same data, together with holotype.

NAME. To emphasize the quite abundant setae on the metaterga.

DESCRIPTION. Length 25-26 $\left(\mathrm{O}^{7}\right)$ or $27-28 \mathrm{~mm}$ $(+)$, width of midbody pro- and metazona 1.6-1.9 and 2.5-2.8 mm $\left(\mathrm{O}^{7}\right)$, or 2.6-3.0 and 3.5-3.8 $\mathrm{mm}(+)$, respectively. Holotype ca $26 \mathrm{~mm}$ long, 1.8 and $2.8 \mathrm{~mm}$ wide on midbody pro- and metazona, respectively. Gen- eral coloration in alcohol rather uniformly marbled brown to grey-brown, more intensely so in anterior $1 / 3$ of body (Figs 114-117), but venter, legs, paratergal calluses, much of epiproct, and usually caudal $1 / 5^{\text {th }}$ or $1 / 6^{\text {th }}$ of metaterga yellowish to whitish. Antennae infuscate distad, antennomere 7 often dark brown. Head between antennal sockets often with a dark brown spot.

In width, head $<$ collum $=$ segments $2-4<5-16$; thereafter body gradually tapering towards telson. Clypeolabral region rather sparsely setose, vertigial region with $1+1$ setae. Antennae slender and rather long, extending behind metatergum $3\left(O^{7}\right)$ or $2(+)$ when stretched dorsally. Paraterga strongly developed (Figs 114-120), especially so in $\sigma^{7}$ compared to ${ }^{2}$, set high, mostly lying at about $1 / 4\left(\sigma^{7}\right)$ or $1 / 3(+)$ of midbody height, thin keels slightly thicker in caudal part in porebearing segments compared to poreless ones, either directed slightly dorsolaterad $\left(\sigma^{7}\right)$ or subhorizontal $(+)$. Collum broadly and regularly rounded laterally, paraterga strongly declined, directed ventrolaterad; paraterga 2 broadly rounded both frontally and caudally, declined more laterad than ventrad, caudal corner clearly extending behind tergal margin; caudal corners of paraterga 3 or both $3^{\text {rd }}$ and $4^{\text {th }}$ narrowly rounded, slightly acutangular, lying within tergal contour; caudal corner 

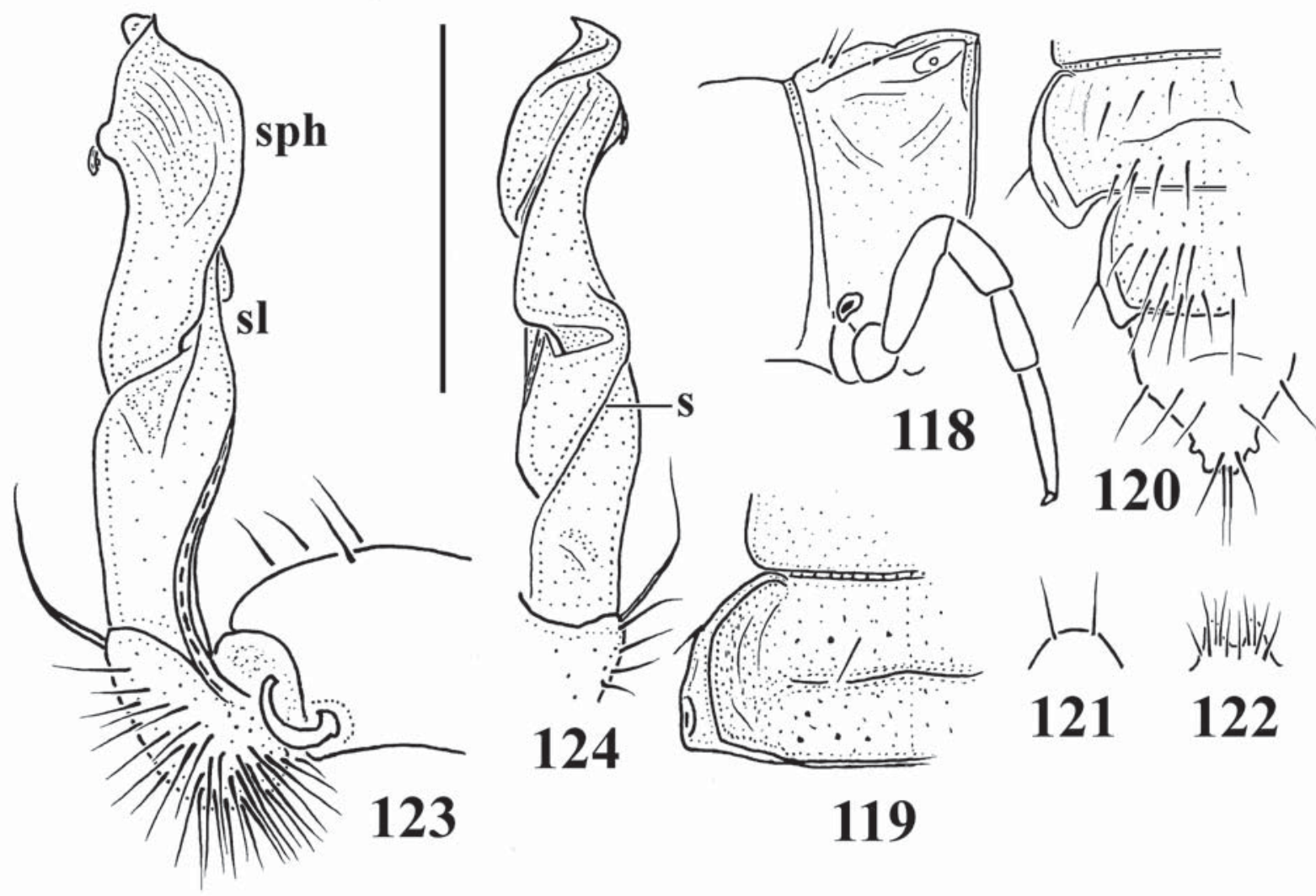

Figs 118-124. Sinomorpha setosa sp.n., O paratype: 118-119 — body segment 10, lateral and dorsal views, respectively; 120 — posterior body part, dorsal view; 121 - hypoproct, ventral view; 122 - sternal lobe between coxae 4, caudal view; 123-124 - right gonopod, mesal and lateral views, respectively. Scale bars: 2.0 (118-122) and $0.3 \mathrm{~mm}(123-124)$

Рис. 118-124. Sinomorpha setosa sp.n., паратип О7: 118-119 - туловищный сегмент 10, соответственно сбоку-сверху; 120 задняя часть тела, вид сверху; 121 - гипопрокт, вид снизу; 122 - стернальная пластинка между тазиками 4, вид сзади; $123-$ 124 - правый гонопод, соответственно изнутри и сбоку. Масштаб 2,0 (118-122) и 0,3 мм (122-124).

of paraterga 5-14 narrowly rounded, subrectangular, also lying within tergal contour until segment 14 thereafter caudal corners of paraterga increasingly narrowly rounded to nearly pointed and increasingly well extended behind rear tergal margin. Calluses narrow, delimited by a distinct sulcus dorsally, porebearing and poreless ones with a similarly strong or weaker ventral sulcus, respectively; lateral margin with one or two evident setigerous indentations in poreless and pore-bearing segments, respectively. Ozopores lateral, slightly visible from above due to a clearly sinuous callus, placed inside an ovoid groove, lying at about caudal quarter of metatergite's length, only in segments 17-19 shifted increasingly close to caudal margin. Body surface shining, at most very delicately granulose and rugulose, generally smooth. Axial line absent. Transverse metatergal sulcus evident, complete, thin, slightly sinuous medially and not reaching bases of paraterga in segments 5-18, nearly smooth at bottom. Tergal setae rather long, abundant, largely ca $1 / 4$ as long as metaterga, collum and metatergum 2 with two transverse, irregular, rather oblique rows of $6+6$ and $6+6$ setae, metaterga 3-5 each with similar two rows of $5+5$ and $5+5$, the latter row located near caudal tergal margin; following metaterga with three rows, $1^{\text {st }}$ and $3^{\text {rd }}$ rows each being composed of 4-5+4-5 setae, whereas $2^{\text {nd }}$ row of $2-4+2-4$ setae placed just in front of $3^{\text {rd }}$ row; setation pattern usually traceable at least as insertion points. Stricture dividing pro- and metazona nearly smooth to very finely striolate down to below paraterga (Figs 118-120). Pleurosternal carinae present, mostly represented by a clear, but increasingly obliterated caudal tooth traceable until segment $10\left(\sigma^{7}\right)$ or $7(+)$, thereafter very poor swellings in a few following segments. Epiproct (Figs 117 \& 120) slightly concave at tip, subapical papillae evident. Hypoproct (Fig. 121) semi-circular, caudal $1+1$ setae strongly separated.

Sternites without modifications, densely setose, cross-impressions very shallow; two high, setose, basally fused cones between $\sigma^{7}$ coxae 4 (Fig. 122). Legs (Figs 114-118) very long, ca 1.8-1.9 ( $\left(\sigma^{1}\right)$ or $1.2-1.3$ times $(+)$ as long as midbody height; prefemora not incrassate; ventral brushes present only in tarsi 1 and 2, thereafter thinning out; adenostyles absent.

Gonopods (Figs 123 \& 124) relatively simple, rather stout; coxite long, subcylindrical, faintly setose distoventrally; telopodite suberect; femorite stout, clearly shorter than acropodite, not twisted, supporting seminal 

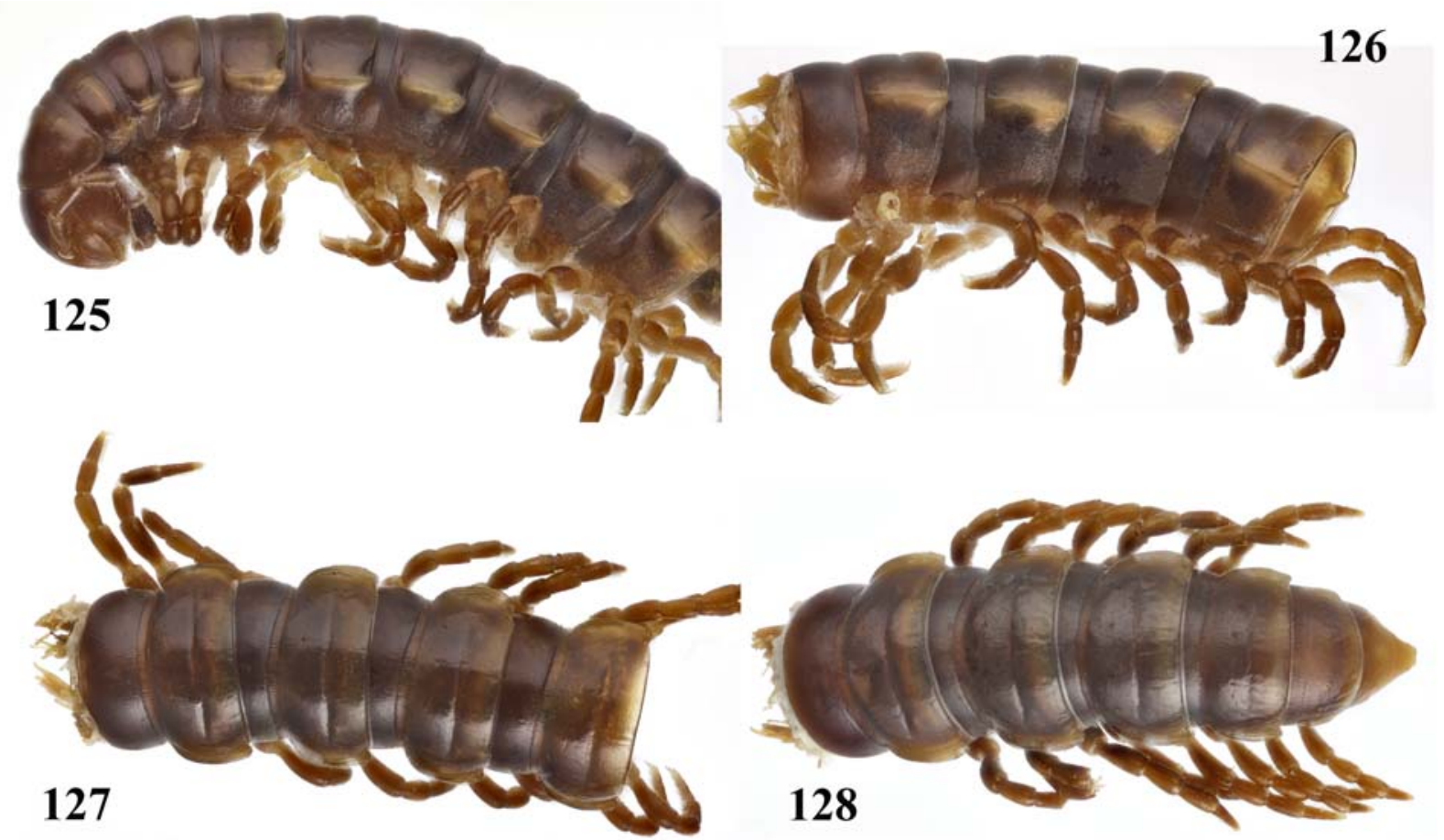

Figs 125-128. Hedinomorpha circofera sp.n., O paratype: 125 - anterior part of body, lateral view; 126-127 - midbody segments, lateral and dorsal views, respectively; 128 - posterior part of body, dorsal view. Photos taken by K. Makarov, not to scale.

Рис. 125-128. Hedinomorpha circofera sp.n., паратип О': 125 - передняя часть тела, сбоку; 126-127 - среднетуловищные сегменты, соответственно сбоку и сверху; 128 - задняя часть тела, сверху. Фото сделаны К. Макаровым, без масштаба.

groove on its mesal side, with a distinct, oblique, lateral sulcus (s) demarcating a postfemoral portion crowned with a broad, stout, lamellar solenophore (sph), the latter with a quite prominent lamina lateralis and a far more strongly developed, apically subtruncate and somewhat twisted lamina medialis, both laminae nearly completely sheathing a long, flagelliform solenomere (sl).

\section{Hedinomorpha circofera sp.n.} Figs $125-136$.

HOLOTYPE $0^{7}$ (SMF), China, Qinghai Prov., Bei Shan National Park [8], $120 \mathrm{~km}$ N of Xining, $102^{\circ} 39^{\prime} \mathrm{E}, 36^{\circ} 56^{\prime} \mathrm{N}, 05$.06.1996, leg. J. Martens.

PARATYPES: $1 \bigcirc^{7}, 2$ 우 (SMF), $1 \bigcirc^{7}$ (ZMUM), same data, together with holotype.

NAME. To emphasize the subcircular solenophore.

DIAGNOSIS. Differs from all five hitherto known congeners (see above and Golovatch [2012]) by the rather stout gonopod femorite which is only about as long as the acropodite, coupled with a slender epiproct, a subcircular, acuminate and serrulate solenophore, as well as a long, nearly straight lateral process (p) at the base of the solenophore (Figs 134-136).

DESCRIPTION. Length ca 21-22 ( $\left.\sigma^{7}\right)$ or 23-24 $\mathrm{mm}(+)$, width of midbody pro- and metazona $1.7-1.8$ and $2.0-2.1 \mathrm{~mm}\left(\mathrm{O}^{7}\right)$, or $2.0-2.1$ and $2.2-2.3 \mathrm{~mm}(+)$, respectively. General coloration in alcohol rather uniformly brown to grey-brown (Figs 125-128), with a rather vague pattern of lighter, yellow to yellowish paraterga, epiproct and, usually, but not always, a narrow band at caudal margin of metaterga; head and segments 1 and 2 red-brown, legs and venter considerably lighter than background, reddish yellow-brown; antennae infuscate distad, antennomere 5 usually brown, $6^{\text {th }}$ and/or $7^{\text {th }}$ dark brown.

In width, head $=$ collum $<$ segments $2-4<$ segments $5-16$; thereafter, body gradually tapering towards telson. Clypeolabral region densely, vertigial region sparsely, setose. Antennae slender, slightly clavate, short, extending only behind metatergum $2\left(O^{7}\right)$ or collum (+) when stretched dorsally; antennomeres 2-6 subequal in length. Paraterga moderately developed, especially so in $\bigcirc^{7}$ compared to $q$ (Figs 125-130), set low, mostly lying at about half of midbody height; paraterga of collum broadly and regularly rounded, strongly declined; paraterga 2-4 directed ventrolaterad, front corner subrectangular, broadly rounded, caudal corner more narrowly rounded, subdentiform, at most only very faintly extending behind rear tergal margin; following paraterga directed more laterad than ventrad, not extending behind tergal margin, in lateral view thick and flat ridges clearly delimited by a deep sulcus only dorsally $\left(\sigma^{r},+\right)$, but devoid of a sulcus ventrally; calluses rather narrow in dorsal view, devoid of lateral indentations, always broadly rounded anteriorly, somewhat acutangular, rounded and dentiform 


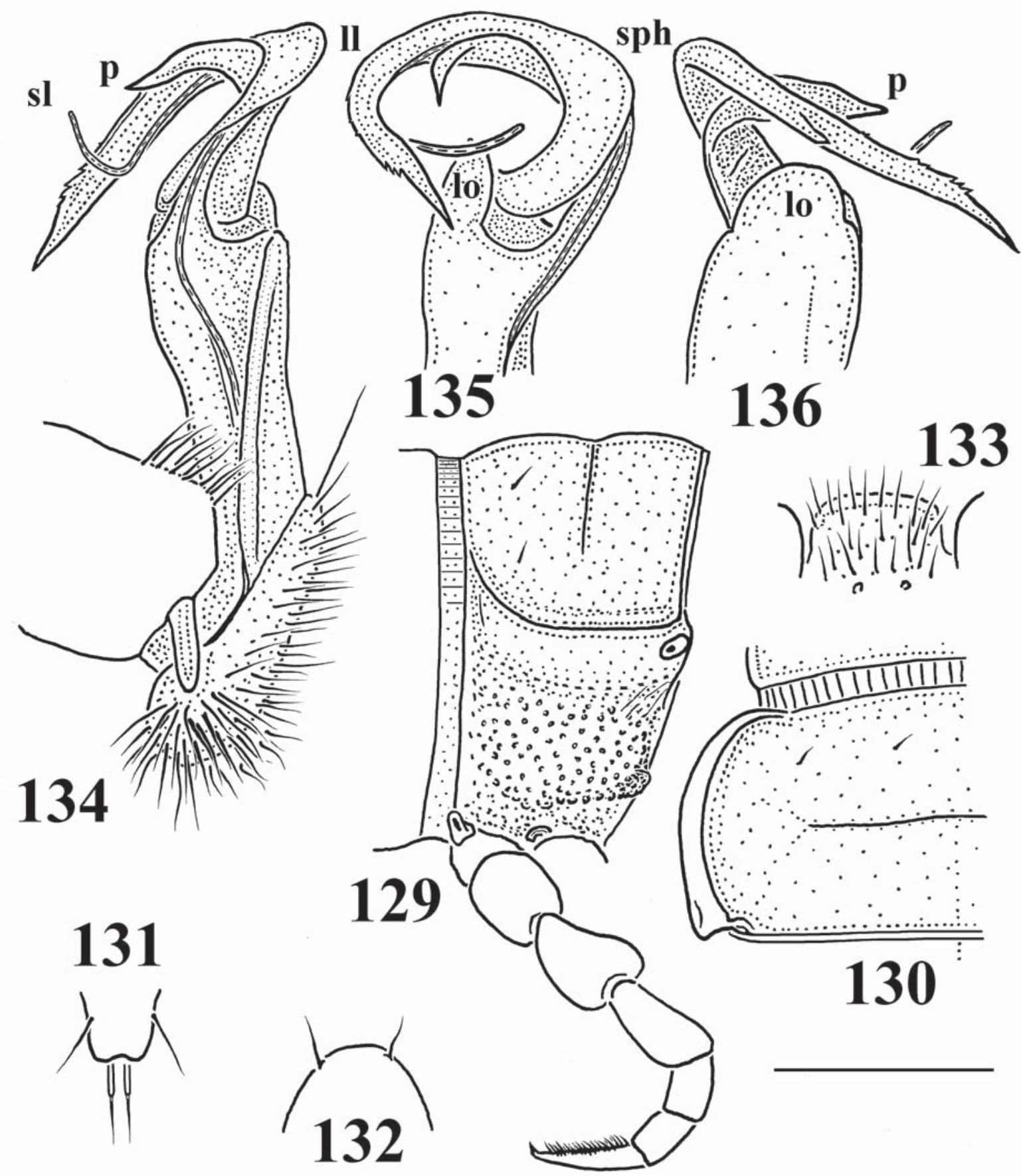

Figs 129-136. Hedinomorpha circofera sp.n., O paratype: 129-130 - body segment 10, lateral and dorsal views, respectively; 131 — epiproct tip, dorsal view; 132 - hypoproct, ventral view; 133 — sternal lobe between coxae 4, caudoventral view; 134-136 - left gonopod, mesal, dorsal and lateral views, respectively. Scale bars: 0.8 (129-133) and $0.4 \mathrm{~mm}(134-136)$.

Рис. 129-136. Hedinomorpha circofera sp.n., паратип О': 129-130 - туловищный сегмент 10, соответственно сбоку и сверху; 131 - кончик эпипрокта, вид сверху; 132 - гипопрокт, вид снизу; 133 - стернальная пластинка между тазиками 4, вид одновременно сзади-снизу; 134-136 - левый гонопод, соответственно изнутри, сверху и сбоку. Масштаб 0,8 (129-133) и 0,4 мм (134-136).

caudally. Ozopores lateral, partly traceable from above only near caudal end of callus, placed inside an ovoid groove near caudal margin of metatergite. Body surface shining and smooth, at most very faintly rugulose, only sides below paraterga clearly microgranulate. Ax- ial line missing. Tergal setae short, ca $1 / 5-1 / 4$ as long as metaterga, arranged in a front transverse row of $2+2$, only sometimes obliterated, but usually retained setae. Transverse metatergal sulcus thin, rather shallow, faintly arcuate forward in the middle, incomplete and not reach- 
ing bases of paraterga in segments 5-18, slightly roughened at bottom (Figs 125-130). Stricture dividing proand metazona quite broad and shallow, finely striate to striolate down to below paraterga (Figs 129 \& 130). Pleurosternal carinae evident, especially large in $\sigma^{7}$ compared to ${ }_{+}$, like complete, arcuated, only faintly declivous, increasingly large and granulated ridges resembling paraterga in segments $2-7$, thereafter abruptly turning into very low ridges with vestigial caudal teeth until segment 11 or 12 (Fig. 129), onward an increasingly strongly obliterated swelling traceable until segment 17. Epiproct (Figs 128 \& 131) usual, not enlarged, faintly concave at tip, subapical papillae wanting. Hypoproct (Fig. 132) semi-circular, caudal 1+1 setae strongly separated.

Sternites without modifications, densely setose, cross-impressions shallow, axial impression especially so; a large, broad, setose, square lamina between $\sigma^{7}$ coxae 4 (Fig. 133). Legs (Figs 125-129) rather short, clearly incrassate in $\sigma^{7}$ compared to + , ca 1.3-1.4 $\left(\sigma^{7}\right)$ or 0.8-0.9 times ( $(+)$ as long as midbody height; prefemora slightly inflated dorsally; ventral brushes present in all tibiae and tarsi but two last pairs; adenostyles absent.

Gonopods (Figs 134-136) relatively complex; coxite long, subcylindrical, setose distoventrally; telopodite much longer than coxite; femorite rather stout, about as long as acropodite, not twisted, supporting seminal groove only on its mesal side, with an indistinct mesal hollow and a mesal terminal sulcus demarcating both a subcircular solenophore (sph) and a flagelliform solenomere (sl) clearly basal to a lateral lobe-shaped extension (lo) of femorite; sph long, slender, directed laterad, acuminate, finely serrulate subapically, largely represented by a laminal lateralis (II), whereas distal half of lamina medialis transformed into a long, clearly curved, knife-shaped process (p), both the laminae sheathing most of sl.

REMARKS. The genus Hedinomorpha Verhoeff, 1933 has recently been reviewed and shown to comprise four accepted species, all keyed [Golovatch, 2012]. Because of the acuminate, serrate, very long and subcircular solenophore, the new species seems to be especially similar to $H$. jeekeli (see above) and $H$. biramipedicula Zhang \& Tang, 1985, from Shanxi, China [Golovatch, 2009a]. Discarding the acuminate solenophore, the new species keys out close to $H$. bucharensis (Lohmander, 1933), from Tajikistan [Golovatch, 2012], but the lateral process at the base of the solenophore in $H$. circofera sp.n. is much longer and nearly pointed. This new species is the first congener to be reported from Qinghai Province, northeastern QinghaiTibetan Plateau, west-central China.

ACKNOWLEDGEMENTS. I am extremely grateful to Jochen Martens (Mainz, Germany) for allowing me to study the bulk of the material treated above. Most of the colour pictures were skillfully taken by K. Makarov (Moscow, Russia), while both E. Schiller and V. Stagl (NHMW, Austria) very helpfully provided photographs of the $\sigma^{7}$ syntypes of Gonobelus sinensis under their care. The map was kindly prepared by Axel Schönhofer (Mainz, Germany). Special thanks go to Wu Donghui (NEIGAE, China) for arranging and partly funding my trip to northeastern China in May and June 2012. The present project was supported in part through a grant released by the Russian Ministry of Education and Science.

\section{References}

Attems C. 1936. Diplopoda of India // Memoirs of the Indian Museum. Vol.11. No.4. P.133-323.

Attems C. 1937. Myriopoda 3. Polydesmoidea I. Fam. Strongylosomidae // Das Tierreich. Lfg.68. S.I-XXII, 1-300.

Chen C.C., Golovatch S.I., Mikhaljova E.V., Chang H.W. 2010a. The millipede genus Anoplodesmus Pocock, 1895, recorded in Taiwan for the first time, with descriptions of two new species (Diplopoda: Polydesmida: Paradoxosomatidae: Sulciferini) // Zootaxa. No.2399. P.20-30.

Chen C.C., Golovatch S.I., Chang H.W. 2010b. Revision of the endemic Taiwanese millipede genus Aponedyopus Verhoeff, 1939, with descriptions of two new species (Diplopoda, Polydesmida, Paradoxosomatidae) // ZooKeys. Vol.72. P.1-21.

Chen C.C., Golovatch S.I., Chang H.W. 2011. The genus Inversispina Zhang, in Zhang, Wang et Zhang, 1997, new to the millipede fauna of Taiwan, with the description of a new species (Diplopoda, Polydesmida, Paradoxosomatidae, Alogolykinae) // Arthropoda Selecta. Vol.20. No.4. P.251-257.

Enghoff H., Golovatch S.I., Nguyen Duc A. 2004. A review of the millipede fauna of Vietnam (Diplopoda) // Arthropoda Selecta. Vol.13. Nos 1-2. P.29-43.

Golovatch S.I. 1984. Contributions to the millipede fauna of Vietnam (Diplopoda) II // Acta Zoologica Hungarica. T.30. Fasc. 12. P.53-77.

Golovatch S.I. 1994. Diplopoda from the Nepal Himalayas: Further Paradoxosomatidae (Polydesmida) // Senckenbergiana biologica. Bd.74. H.1-2. S.163-182.

Golovatch S.I. 1995. On several new or poorly-known Oriental Paradoxosomatidae (Diplopoda, Polydesmida), III // Arthropoda Selecta. Vol.4. No.2. P.89-97.

Golovatch S.I. 1996. The millipede family Paradoxosomatidae on Borneo, with contributions to the faunas of some other islands of the Sunda area (Diplopoda, Polydesmida) // Rev. suisse Zool. T.103. Fasc.1. P.151-193.

Golovatch S.I. 1997. On several new or poorly-known Oriental Paradoxosomatidae (Diplopoda: Polydesmida), V // Arthropoda Selecta. Vol.5. Nos 3-4. P.131-141 (for 1996).

Golovatch S.I. 1998. On several new or poorly-known Oriental Paradoxosomatidae (Diplopoda: Polydesmida), VI // Arthropoda Selecta. Vol.6. Nos 3-4. P. 35-36 (for 1997).

Golovatch S.I. 2009a. On several new or poorly-known Oriental Paradoxosomatidae (Diplopoda: Polydesmida), VIII // Arthropoda Selecta. Vol.18. Nos 1-2. P.1-7.

Golovatch S.I. 2009b. On several new or poorly-known Oriental Paradoxosomatidae (Diplopoda: Polydesmida), IX // Arthropoda Selecta. Vol.18. Nos 3-4. P.119-124.

Golovatch S.I. 2011. On several new or poorly-known Oriental Paradoxosomatidae (Diplopoda: Polydesmida), XI // Arthropoda Selecta. Vol.20. No.4. P.259-266.

Golovatch S.I. 2012. On several new or poorly-known Oriental Paradoxosomatidae (Diplopoda: Polydesmida), XII // Arthropoda Selecta. Vol.21. No.1. P.1-12.

Golovatch S.I., Enghoff H. 1993. Review of the millipede genus Tylopus, with descriptions of new species from Thailand (Diplopoda, Polydesmida, Paradoxosomatidae) // Steenstrupia. Vol.19. No.3. P.85-125.

Golovatch S.I., Wytwer J. 2001. On two new species of the millipede family Paradoxosomatidae from Java, with reviews of the genera Opisthodolichopus Verhoeff, 1941 and Nesorthomor- 
pha Jeekel, 1980 (Diplopoda: Polydesmida) // Annales Zoologici, Warszawa. Vol.51. No.4. P.403-408.

Hoffman R.L. 1961. Two new diplopod genera from western China (Polydesmida: Strongylosomatidae) // Ann. Mag. Nat. Hist. Ser.13. Vol.3. P.533-543.

Hoffman R.L. 1963. A contribution to the knowledge of Asiatic strongylosomoid Diplopoda (Polydesmida: Strongylosomatidae) // Ann. Mag. Nat. Hist. Ser.13. Vol.5. P.577-593.

Hoffman R.L. 1980. Classification of the Diplopoda. Genève: Muséum d'histoire naturelle. 237 pp. (for 1979).

Jeekel C.A.W. 1953. Two new Strongylosomidae from Indochina (Diplopoda, Polydesmida) // Beaufortia. Vol.2. No.29. P. 1-8.

Jeekel C.A.W. 1965. A revision of the Burmese Paradoxosomatidae (Diplopoda, Polydesmida) in the Museo Civico di Storia Naturale at Genoa (Part I) // Tijdschrift voor Entomologie. Deel 108. Afl.5. P.95-144.

Jeekel C.A.W. 1968. On the classification and geographical distribution of the family Paradoxosomatidae(Diplopoda, Polydesmida). Privately published. Rotterdam: Academisch Proefschrift (PhD Thesis). $162 \mathrm{pp}$.

Jeekel C.A.W. 1980. A revision of the Burmese Paradoxosomatidae (Diplopoda, Polydesmida) in the Museo Civico di Storia Naturale at Genoa (Part III) // Tijdschrift voor Entomologie. Deel 123. Afl.3. P.71-88

Korsós Z., Golovatch S.I. 1989. Addenda to the millipede fauna of Vietnam (Diplopoda) // Acta Zoologica Hungarica. Vol.35. P.211-220.

Likhitrakarn N., Golovatch S.I., Prateepasen R., Panha S. 2010. Review of the genus Tylopus Jeekel, 1968, with descriptions of five new species from Thailand (Diplopoda, Polydesmida, Paradoxosomatidae) // ZooKeys. Vol.72. P.23-68.

Likhitrakarn N., Golovatch S.I., Panha S. 2011. Revision of the Southeast Asian genus Orthomorpha Bollman, 1893, with the proposal of a new genus (Diplopoda, Polydesmida, Paradoxosomatidae) // ZooKeys. Vol. 131. P.1-161.

Liu W.x., Luo X.z. 2013. A new species of the millipede genus Tylopus Jeekel from southern China (Diplopoda, Polydesmida, Paradoxosomatidae) // Acta Zootaxonomica Sinica. Vol.38. No.1. P.50-52.

Mikhaljova E.V., Korsós Z. 2003. Millipedes (Diplopoda) from Korea, the Russian Far East, and China in the collection of the Hungarian Natural History Museum // Acta Zoologica Academiae Scientiarum Hungaricae. T.49. Fasc.3. P.215-242.

Mršić N. 1996. On three new Paradoxosomatidae from Malaysia (Diplopoda Polydesmida) // Arthropoda Selecta. Vol.5. Nos 12. P.139-144.

Nguyen Duc A. 2010. The millipede genus Anoplodesmus Pocock, 1895 in Vietnam (Diplopoda: Polydesmida: Paradoxosomatidae) // Zootaxa. No.2649. P.52-60.

Zhang C.Z., Wang D.Q., Zhang F.X. 1997. [Two new genera and four new species of Diplopoda from Wuling Mountains area] // Song D.X. (ed.). Invertebrates of Wuling Mountains area, Southwestern China. Beijing: Science Press. P.508-522 [in Chinese, with English summary].

Responsible editor K.G. Mikhailov 